\title{
New perspectives on coastal landscape reconstruction during the Late Quaternary: A test case from central Israel
}

\author{
Gilad Shtienberg ${ }^{\mathrm{a}, *}$, Justin K. Dix ${ }^{\mathrm{b}}$, Joel Roskin ${ }^{\mathrm{c}, \mathrm{d}, \mathrm{e}}$, Nicolas Waldmann ${ }^{\mathrm{c}}$, Revital Bookman ${ }^{\mathrm{c}}$, Or M. Bialik ${ }^{\mathrm{c}}$, \\ Naomi Porat ${ }^{\mathrm{f}}$, Nimer Taha ${ }^{\mathrm{c}}$, Dorit Sivan ${ }^{\mathrm{a}, \mathrm{e}}$ \\ ${ }^{a}$ Department of Maritime Civilizations, L. H. Charney School of Marine Sciences, University of Haifa, Haifa 3498838, Israel \\ ${ }^{\mathrm{b}}$ School of Ocean and Earth, National Oceanography Centre Southampton, University of Southampton, European Way, Southampton SO14 $3 Z$ Z, UK \\ ${ }^{c}$ Dr. Moses Strauss Department of Marine Geosciences, L.H. Charney School of Marine Sciences, University of Haifa, Haifa 3498838, Israel \\ ${ }^{\mathrm{d}}$ School of Sciences, Achva Academic College, Mobile Post Shikmim, Arugot 7980400, Israel \\ e Leon Recanati Institute for Maritime Studies (RIMS), University of Haifa, Haifa 3498838, Israel \\ ${ }^{\mathrm{f}}$ Geological Survey of Israel, 30 Malkhe Israel Street, Jerusalem 95501, Israel
}

A R T I C L E I N F O

Article history:

Received 19 August 2016

Received in revised form 2 December 2016

Accepted 22 December 2016

Available online $\mathrm{xxx}$

Keywords:

Stratigraphic architecture

Eastern Mediterranean

Coastal lowlands

Aeolianite cliff

Quaternary-landscape evolution

Siliciclastic sequence

\begin{abstract}
A B S T R A C T
The stratigraphic architecture of coastal plains is determined by the interactions between local (e.g. fluvial processes and topography), regional (e.g. climate) and global (e.g. sea level) forcing factors, primarily during the Late Quaternary Period. Detailed stratigraphic and sedimentological analyses of boreholes, cored between coastal ridges in the lowlands, coupled with optically stimulated luminescence (OSL) dating, and integrated with existing onshore and offshore databases, has enabled a 4-D reconstruction of the evolution of the coast of Israel during the last glacial-interglacial cycle. This model revealed that Nilotic-sourced littoral sand, intermittently transported inland by wind, has either been lithified into aeolianite or pedogenized into orange-brown palaeosol from about $100 \mathrm{ka}$ to $8 \mathrm{ka}$. Dark silty clay wetlands were deposited between the aeolian coastal ridges adjacent to streams which cut the Israeli coastal plain and flow westward, from the Last Glacial Maximum until the onset of the Holocene. These units are topped by beach and aeolian quartz sand dated to 6.6-0.1 ka. Diachronous thicknesses and lithological dissimilarities were identified between the sections studied and previous reports on adjacent coastal aeolianite ridges. Streams were found to be a dominant control on the stratigraphical composition and related facies architecture due to fluvial-induced erosion. Consequently, the relief variations between the lowland and cliff controlled aeolian pedogenesis as well as alluvial processes from about 80 to $5 \mathrm{ka}$. Climate, mainly influenced by precipitation and dust input, induced pedogenic processes; while sea level lowstand during the Last Glacial Maximum is shown to have hindered sediment deposition in the shallow offshore, which in turn affected aeolian transport, reducing sediment accumulation on the palaeo-coastal plain. The palaeoenvironmental model presented in the current study serves as an example for understanding the evolution of similar low-latitude siliciclastic-rich low-gradient shelf-coastal areas during the last glacial-interglacial cycle. Furthermore, it demonstrates the influence of local to global forcing factors on these environments.
\end{abstract}

(C) 2016 Published by Elsevier Ltd.

\section{Introduction}

During the Quaternary, relative sea level (RSL) fluctuations have had a major influence on the sedimentary archives of continental shelves and the adjacent coastal plains. The effect of sea-level on accommodation space is one of the major influences on aggradation and erosion, and hence on the distribution of sediments across the shelves. Additional interconnected factors operating at all scales, such as tides, waves, storms, precipitation, sediment input and vegetation cover, also play important roles in the depositional and erosional phases that shape the litho-stratigraphic architecture. Moreover, local processes, such as stream-courses, modify pre-existing depositional patterns and induce irregular erosion patterns, while local relief variations affect soil formation processes (Dan et al., 1968; Paton et al., 1995; Yaalon, 1997).

\footnotetext{
* Corresponding author.

Email address: gshtienb@campus.haifa.ac.il (G. Shtienberg)
}

Aeolianite-palaeosol-sand sequences, which are characteristic of low latitude, siliciclastic shallow shelf and coastal areas, reflect this dynamic interaction between accommodation space, sediment supply and climate changes (Hearty et al., 2007; Brooke et al., 2003; Bateman et al., 2004; Zazo et al., 2005; Faust et al., 2015). Consequently, detailed chronostratigraphic study can potentially reveal changes in the environmental conditions during the Quaternary (Huntley et al., 1993, 1994; Rose et al., 1999; Huntley and Prescott, 2001; Preusser et al., 2002; Munyikwa, 2005; Tripaldi and Forman, 2007; Amorosi et al., 2009; Fitzsimmons et al., 2009; Roskin et al., 2011a; Brooke et al., 2014; Rowe and Bristow, 2015a, 2015b). Coastal stratigraphic studies have been conducted across the Mediterranean basin, in Spain (Fornós et al., 2009; Mauz et al., 2012), Sardinia (Coltorti et al., 2010; Thiel et al., 2010), Tunisia (Mauz et al., 2009, 2012; Elmejdoub et al., 2011), Cyprus (Tsakalos, 2016) and Egypt (El-Asmar, 1994; El-Asmar and Wood, 2000). These are characterized by alternating Late Pleistocene aeolianites, palaeosol units and accompanying alluvial facies. These studies have mainly focused 
on the correlation between dune formation and late Quaternary sea level oscillation, while less attention has been given to the coastal geomorphic response to climate, aeolian and alluvial processes. Furthermore, the studied units were usually site-specific, and not correlated with the adjacent terrestrial and submerged stratigraphies.

The Late Quaternary coastal palaeogeography of Israel has been studied since the 1940s in an attempt to correlate the coastal outcrop stratigraphy with transgressive and regressive sea level phases (Avnimelech, 1950). Later works concentrated on radiometric (luminescence and radiocarbon) ages for the central coastal aeolianite cliff sequences which yield ages younger than about $75 \mathrm{ka}$ (Engelmann et al., 2001; Frechen et al., 2001, 2002; Porat et al., 2004; Moshier et al., 2010; Mauz et al., 2013). Hardly any attention has been paid to the submerged stratigraphy and to the sequences of lowlands located between coastal ridges. These locations potentially include palaeosols containing valuable climate indicators, and useful evidence for reconstructing past environments (Gvirtzman and Wieder, 2001; Zazo et al., 2005; Fitzsimmons et al., 2009). The relatively short time-frame attributed to the exposed sequences; the paucity of adequate subsurface chronostratigraphic studies; the absence of correlation of the coastal cliffs to the nearby lowland areas (Fig. 1c and d); and the lack of connection of the inner shelf to the coastal stratigraphy, have all hindered detailed reconstruction of the stratigraphic architecture of coastal areas and the investigation of the dominant long-term factors that affect the evolution of the coastal landscape.

The present study investigates the eustatic, climatic and local controls on the morphogenesis of the coastal system during the Late Quaternary of a selected study area located in central Israel (Fig. 1 for location). The findings are correlated in a wider environmental and climatic perspective, enabling the construction of an evolutionary model of the coastal environment over the last glacial-interglacial period. These goals were achieved through high-resolution sedimentological and chronostratigraphic studies of seven cores drilled in the Alexander-Hadera lowland area adjacent to the mouths of Nahal (Stream in Hebrew; N.) Hadera and N. Alexander (Fig. 1 for location). The new data were integrated with an existing detailed onshore and offshore database. The study area was selected based on: (1) the inclusion of various morphologies (aeolian dune system, sand sheets, wetlands and streams), which provide the optimal conditions for studying the interplay of these morphologies with sea level over time; (2) the sensitivity of the stream valleys to climate (precipitation) and hydrological influences (floods); (3) previous studies of the stratigraphic architecture of both the adjacent terrestrial (Neber, 2002) and inner shelf (Shtienberg et al., 2016) environments; and (4) radiometrically-dated sequence of the coastal cliff section (Frechen et al., 2002).
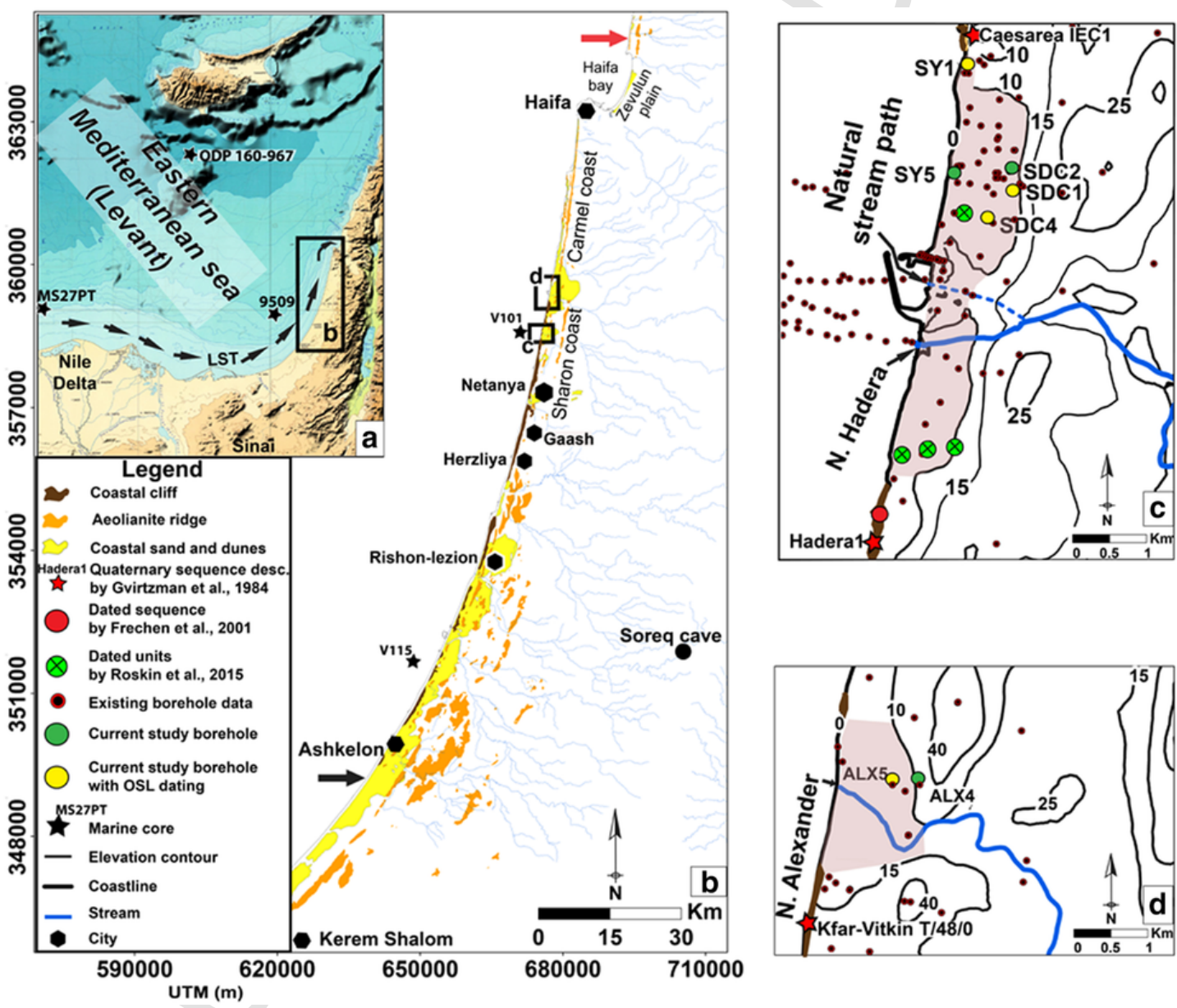

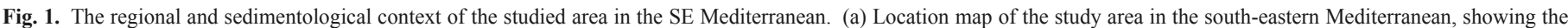

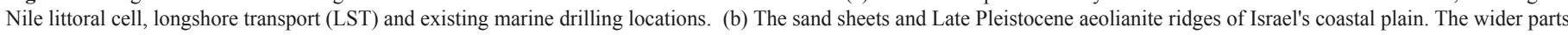

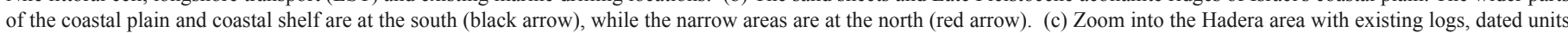

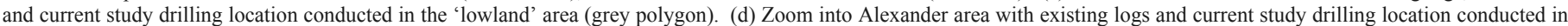
the 'lowland' area (grey polygon). (For interpretation of the references to colour in this figure legend, the reader is referred to the web version of this article.) 


\section{Regional setting}

Israel's Mediterranean coastal plain is an ideal location for studying Late Quaternary coastal evolution. Relative sea levels of the Mediterranean Sea generally track eustatic sea-level changes (Lambeck and Bard, 2000; Galili et al., 2007; Sivan et al., 2016), and it is hypothesised that the Late Pleistocene synoptic regime over the Mediterranean was similar to the present (Enzel et al., 2008). Israel's coast is considered tectonically stable, at least since Marine Isotope Stage (MIS) 5e (Sivan et al., 1999; Galili et al., 2007; Mauz et al., 2013; Sivan et al., 2016), with low isostatic uplift rates of about $0.1 \mathrm{~mm} /$ year in the Holocene (Sivan et al., 2001; Anzidei et al., 2011; Toker et al., 2012), and about $0.05 \mathrm{~mm} /$ year over about the last $125 \mathrm{ka}$ (Sivan et al., 2016).

The $190 \mathrm{~km}$-long coastal plain of Israel widens from about $3 \mathrm{~km}$ in the north to about $15 \mathrm{~km}$ in the south (Almagor and Hall, 1984). The continental shelf follows the same spatial pattern, widening from about $10 \mathrm{~km}$ in the north to about $20 \mathrm{~km}$ in the south (Fig. 1b), with the shelf break situated at water depths of $80-130 \mathrm{~m}$ below mean sea level (bmsl; Almagor et al., 2000; Sade et al., 2006). The sediments that cover the shelf and coastal plain mostly comprise of Nile derived quartz sand 1 to $9 \mathrm{~m}$ thick (Fig.1a and b; Picard, 1943; Emery and Neev, 1960; Pomerancblum, 1966; Neev et al., 1978; Zviely et al., 2009; Davis et al., 2012; Almagor et al., 2000; Zviely et al., 2006; Schattner et al., 2010, 2015; Roskin et al., 2016; Shtienberg et al., 2016). This allogenic material is transported to the region through longshore currents, and is mostly deposited at water depths shallower than $40 \mathrm{~m} \mathrm{bmsl}$. The sand flux diminishes northwards and terminates at Haifa Bay (Fig. 1b for location) (Zviely et al., 2006; Hyams-Kaphzan et al., 2008).

During the Quaternary, wave- and wind-induced currents transported these sediments landwards to the beach, from where they were windblown inland to form sand sheets and sand dunes (Fig. 1b; Gvirtzman et al., 1998; Porat et al., 2004). The dunes later fossilized through dissolution of carbonate by meteoric waters and calcite cementation, forming calcareous aeolianite sandstone ridges (locally known as kurkar; Fig. 1b; Yaalon, 1967; Gavish and Friedman, 1969; Almagor et al., 2000). Up to eighteen aeolianite ridges trending parallel-sub-parallel to the shoreline rise above the surface of the coastal plain and the relatively flat sea-bed (Almagor et al., 2000; Mauz et al., 2013; and references therein). The relationship between the spatial and temporal patterns of the coastal ridges and past sea-level changes is still not well established (Sivan and Porat, 2004; Mauz et al., 2013, Shtienberg et al., 2016) due to the absence of an RSL curve, dating resolution and radiometric errors.

The Late Pleistocene aeolianite coastal ridges of Israel, located up to $3 \mathrm{~km}$ east of the present shoreline, are overlain by a thick brown-red sandy clayey loam soil (Chromic Luvisol) locally known as hamra (Gvirtzman et al., 1983, 1998; Engelmann et al., 2001). This soil sequence comprises sub-units that differ in their lithological characteristics (Frechen et al., 2002; Porat et al., 2004). These palaeosol sub-units have a wide range of ages, sometimes synchronous with the aeolianite ridges, and sometimes younger, dating from about 87 to about $8 \mathrm{ka}$ (Gvirtzman and Wieder, 2001; Frechen et al., 2002; Porat et al., 2004; Sivan and Porat, 2004; Mauz et al., 2013).

Unlike the beach ridge sequence chronology, the coastal lowland sequences adjacent to the stream path and mouths have not been studied in detail. Boreholes drilled in the Carmel coast and Zevulun Plain lowlands (Fig. 1b), reveal calcareous sandstone units down to $15 \mathrm{~m}$ below the present surface, dated to $101 \pm 11$ and $131 \pm 16 \mathrm{ka}$ (Sivan and Porat, 2004; Elyashiv, 2013) respectively, which are older than the base aeolianite of the coastal cliff (Engelmann et al., 2001; Frechen et al., 2002; Porat et al., 2004). Dark brown to brownish-red clayey sand to sandy clay palaeosols uncomfortably overlay the sandstone units in the Carmel coast and Zevulun Plain lowlands. These sandy soils range from about 92 to about $8 \mathrm{ka}$, and contain hiatuses within units that are yet to be explored (Kadosh et al., 2004; Sivan and Porat, 2004; Cohen-Seffer et al., 2005; Elyashiv, 2013; Roskin et al., 2015).

As sea level rose during the Holocene, the shoreline migrated eastwards, flooding the shallow shelf (depth shallower than $-20 \mathrm{~m}$ ) at about $8 \mathrm{ka}$ (Sivan et al., 2001, 2004). Nilotic sand started to accumulate on the coast, and covered the coastal ridges and lowland palaeosols at about $7 \mathrm{ka}$ (Engelmann et al., 2001; Frechen et al., 2001; Porat et al., 2004). At about $3 \mathrm{ka}$, sea level stabilized at approximately the present mean sea level (MSL: Sivan et al., 2001, 2004). During this time, the ridge that currently marks the shoreline was eroded, forming coastal cliffs which exposed its internal architecture (Katz and Mushkin, 2013).

\section{Methods}

\subsection{Compilation of existing datasets}

Previously acquired stratigraphic, chronostratigraphic, geomorphic and spatial data from the study area were integrated into a single geospatial database using ArcGIS 10.3.1. Existing borehole data were collected from published research papers and reports (Fig. 1c; supplements). The borehole compilation locations, elevations, and lithological descriptions were modified in ArcGIS tables. Existing DEM models ( $4 \times 4 \mathrm{~m}$ bin size), soil maps, rectified aerial photographs and chronostratigraphic data of the study area were also uploaded to the ArcGIS database. Based on the relevant lithological data, the submerged calcareous sandstone top stratum topography was mapped using the ArcGIS Topo to Raster module (Fig. 2).

\subsection{New borehole drillings and petro-sedimentological analyses}

In the current study, the locations of new drillings, all in the lowland areas, were chosen, based on a reconstructed shallow top calcareous sandstone surface (Fig. 2). Coring was conducted along a $10 \mathrm{~km}$-long N-S transect extending to $1.5 \mathrm{~km}$ east of the current shoreline by a Geo-probe 6620DT vibrocorer. Locations and elevations of seven continuous cores penetrating down to $15 \mathrm{~m}$ were measured using a Proflex 500 RTK-GPS with precisions of XY $= \pm 1 \mathrm{~cm}$ and $\mathrm{Z}= \pm 5 \mathrm{~cm}$ respectively (Fig. 1c and d). Magnetic susceptibility (MS) and density were measured every $2 \mathrm{~cm}$ for each core. The measurements were conducted using a Geotek multi-sensor core logger equipped with a Bartington loop sensor, compatible for small diameter cores, producing a $0.565 \mathrm{kHz}$ magnetic field.

The boreholes were sectioned lengthwise and logged, including Munsell colours. Brightness values ranging from 0 to 254 were assigned for each pixel though digital photography based on its colour appearance. Particle-size distribution (PSD) was carried out on 300 samples from the seven cores. The measurements, with a particle range of $0.02-2000 \mu \mathrm{m}$, were conducted with a Beckman Coulter LS 13320 laser diffraction particle size analyzer.

Total organic carbon (TOC) and inorganic carbon (IC) measurements were conducted on 210 freeze-dried sediment samples of $0.2 \mathrm{~g}$. TOC and IC were measured using a PrimacsSLC TOC analyzer. X-ray fluorescence (XRF) analysis was undertaken on 60 samples from Boreholes SY1 and ALX5, using the EX-310LC(ED) instrument, in an excitation voltage of $35 \mathrm{kV}$, with an $8 \mathrm{~mm}$ diameter beam. Faunal 


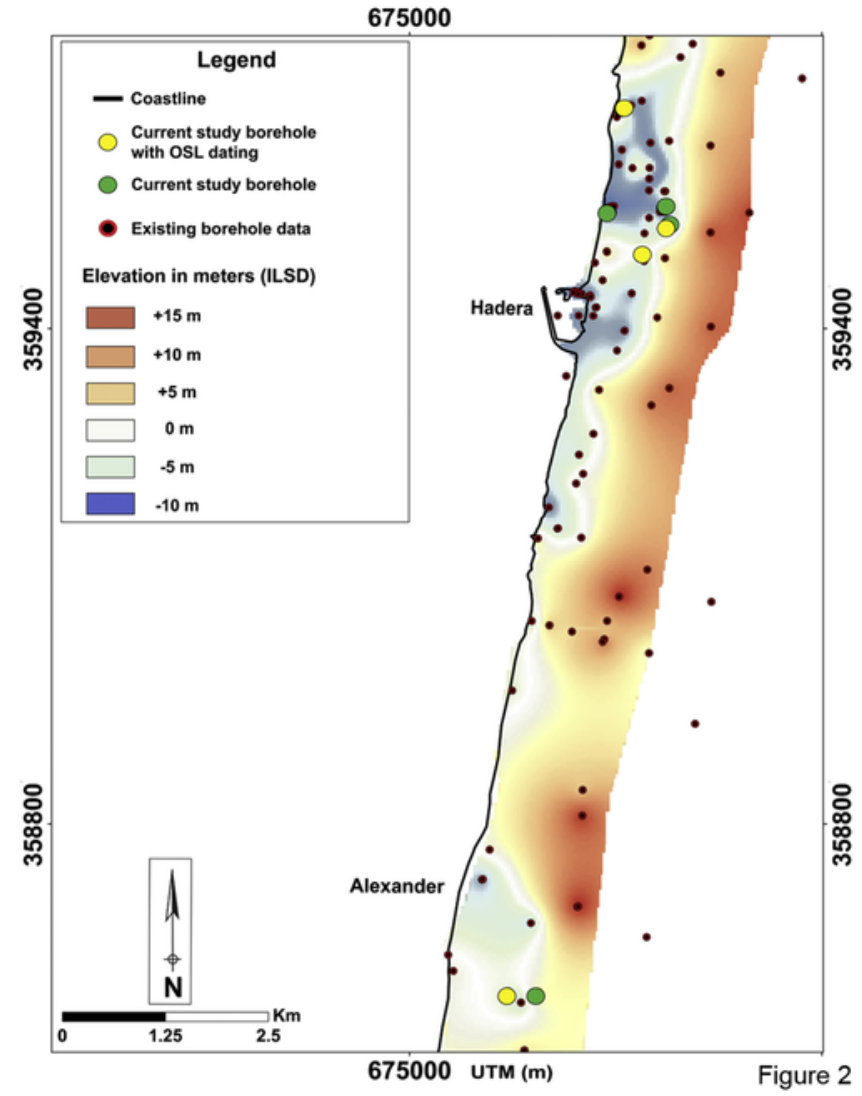

Fig. 2. Reconstructed topography of the Late Pleistocene calcareous sandstone surface of various dates based on existing log data. The current study drillings (yellow and green circles) were carried out in the reconstructed lowland areas of Hadera and Alexander. (For interpretation of the references to colour in this figure legend, the reader is referred to the web version of this article.)

analysis was carried out on 30 selected samples from Borehole ALX5. Samples of $10 \mathrm{~g}$ dry weight were washed over a $63 \mathrm{~mm}$ sieve and dried. Sub-samples of $5 \mathrm{~g}$ were subjected to palaeontological analysis by Dr. Avnaim-Katav. Pollen analysis of ten samples was carried out by Dr. Langgut at the Laboratory of Archaeobotany and Ancient Environments, Tel Aviv University. Thin sections of the basal unit were analysed using an Olympus BX53-P petrographic microscope. Their structures and diagenetic features were classified, described and interpreted following Wright and Tucker (1991),Wright (1992), Adams and Mackenzie (1998).

\subsection{Optically stimulated luminescence (OSL) dating}

Sixteen OSL samples were taken from Boreholes SY1, SDC1, SDC4 and ALX5 (Fig. 1c and d). The samples were prepared and measured at the Luminescence Laboratory of the Geological Survey of Israel, Jerusalem. Quartz grains $(125-150 \mu \mathrm{m})$ were extracted using routine laboratory procedures under subdued orange light (Davidovich et al., 2012). After wet-sieving to the desired grain size, carbonates were dissolved with $8 \% \mathrm{HCl}$. The rinsed and dried samples were passed through a Frantz magnetic separator to remove heavy minerals, undissolved carbonates, and most feldspars. A 40-min rinse in 40\% hydrofluoric acid (HF) dissolved any remaining feldspars and etched the quartz grains, followed by rinsing in $16 \% \mathrm{HCl}$ overnight to remove any fluorides which may have precipitated.

OSL measurements were carried out on a refurbished Risø DA-12 or DA-20 TL/OSL reader equipped with an integral ${ }^{90} \mathrm{Sr} \beta$ source, with dose rates of $2.8 \mathrm{~Gy} / \mathrm{min}$ or $2.3 \mathrm{~Gy} / \mathrm{min}$, respectively. Stimulation was achieved with blue LEDs, and detected through $7 \mathrm{~mm}$ U-340 filters. The SAR protocol of Murray and Wintle (2000) was used to determine the equivalent dose (De). Preheat and cut heat temperatures of $260^{\circ} \mathrm{C}$ and $220^{\circ} \mathrm{C}$ were selected respectively, after dose recovery tests showed that with such preheats known doses can be recovered to within $95 \%$. Individual aliquots (13 to 20 for each sample) were measured, and the average De errors were calculated using the unweighted mean and standard deviation. OSL ages are presented as thousands of years (ka) before 2015 .

The sixteen OSL ages obtained in this study are considered reliable (Table 1), with bright and rapidly decaying OSL signals, recycling ratios within $5 \%$ of unity, little recuperation and no feldspar contamination. De distributions are mostly tight (over-dispersion values from $8 \%$ to $25 \%$ ), indicating that the samples were well bleached

Table 1

Current study boreholes: optically stimulated luminescence (OSL) laboratory data and ages.

\begin{tabular}{|c|c|c|c|c|c|c|c|c|c|c|c|c|c|c|c|c|}
\hline $\begin{array}{l}\text { Site, } \\
\text { Core } \\
\text { name, } \\
\text { and } \\
\text { Sample }\end{array}$ & $\begin{array}{l}\text { Lithological } \\
\text { unit/facies }\end{array}$ & $\begin{array}{l}\text { Sample } \\
\text { depth } \\
\text { relative } \\
\text { to } \\
\text { ILSD } \\
\text { (m) }\end{array}$ & $\begin{array}{l}\text { Moisture } \\
(\%)\end{array}$ & $\begin{array}{l}\text { Grain } \\
\text { size }(\mu \mathrm{m})\end{array}$ & $\begin{array}{l}\mathrm{K} \\
(\%)\end{array}$ & $\begin{array}{l}\mathrm{U} \\
(\mathrm{ppm})\end{array}$ & $\begin{array}{l}\text { Th } \\
(\mathrm{ppm})\end{array}$ & $\begin{array}{l}\text { Ext. } \alpha \\
(\mu \mathrm{Gy} / \\
\text { a) }\end{array}$ & $\begin{array}{l}\text { Ext. } \beta \\
(\mu \mathrm{Gy} / \mathrm{a})\end{array}$ & $\begin{array}{l}\text { Ext. } \gamma \\
(\mu \mathrm{Gy} / \mathrm{a})\end{array}$ & $\begin{array}{l}\text { Cosmic } \\
(\mu \mathrm{Gy} / \mathrm{a})\end{array}$ & $\begin{array}{l}\text { Total dose } \\
(\mu \mathrm{Gy} / \mathrm{a})\end{array}$ & $\begin{array}{l}\text { No. } \\
\text { of } \\
\text { discs }\end{array}$ & $\begin{array}{l}\text { OD } \\
(\%)\end{array}$ & De (Gy) & Age (ka) \\
\hline \multicolumn{17}{|c|}{ Alexander (ALX5) } \\
\hline ALX-1 & $\mathrm{F} 5 / \mathrm{a}$ & 1.8 & 6 & $125-180$ & 0.25 & 0.35 & 0.74 & 1 & 221 & 127 & 189 & $538 \pm 11$ & $\begin{array}{r}18 / \\
18\end{array}$ & 15.7 & $1.9 \pm 0.3$ & $3.6 \pm 0.5$ \\
\hline ALX-2 & $\mathrm{F} 5 / \mathrm{a}$ & 1 & 14 & $125-180$ & 0.14 & 0.77 & 1.2 & 2 & 193 & 153 & 174 & $522 \pm 15$ & $\begin{array}{r}20 / \\
20\end{array}$ & 12.3 & $3.4 \pm 0.4$ & $6.6 \pm 0.9$ \\
\hline ALX-3 & $\mathrm{F} 4$ & 0.35 & 22 & $74-210$ & 0.76 & 1.60 & 8.7 & 7 & 744 & 623 & 158 & $1531 \pm 63$ & $\begin{array}{r}17 / \\
18\end{array}$ & 11.7 & $16.5 \pm 2.1$ & $10.8 \pm 1.4$ \\
\hline ALX-4 & $\mathrm{F} 4$ & 0 & 21 & $74-210$ & 0.74 & 1.61 & 8.5 & 7 & 738 & 619 & 154 & $1518 \pm 63$ & $\begin{array}{r}18 / \\
18\end{array}$ & 18.3 & $15.6 \pm 3$ & $10.3 \pm 2.0$ \\
\hline ALX-5 & $\mathrm{F} 4$ & -1.2 & 22 & $74-210$ & 0.90 & 1.83 & 8.7 & 7 & 845 & 672 & 134 & $1658 \pm 69$ & $\begin{array}{r}18 / \\
18\end{array}$ & 17.4 & $35.1 \pm 6.5$ & $21 \pm 4$ \\
\hline ALX-6 & $\mathrm{F} 3$ & -1.7 & 18 & $74-210$ & 0.78 & 1.52 & 6.8 & 6 & 739 & 568 & 130 & $1443 \pm 53$ & $\begin{array}{r}18 / \\
18\end{array}$ & 24.5 & $52 \pm 13$ & $36 \pm 9$ \\
\hline ALX-7 & F3 & -2 & 16 & $74-210$ & 0.84 & 1.20 & 5.8 & 5 & 735 & 521 & 127 & $1388 \pm 50$ & $\begin{array}{r}14 / \\
14\end{array}$ & 23.8 & $49.8 \pm 11.2$ & $36 \pm 8$ \\
\hline ALX-8 & F3 & -2.2 & 10 & $90-150$ & 0.86 & 1.08 & 4.7 & 5 & 758 & 496 & 120 & $1378 \pm 51$ & $\begin{array}{r}14 / \\
14\end{array}$ & 17.8 & $59.7 \pm 11.7$ & $43 \pm 9$ \\
\hline ALX-9 & F3 & -2.5 & 16 & $90-150$ & 0.81 & 0.95 & 4.2 & 4 & 658 & 426 & 115 & $1202 \pm 43$ & $\begin{array}{r}18 / \\
18\end{array}$ & 10.7 & $50.6 \pm 5.7$ & $42 \pm 5$ \\
\hline ALX-10 & F3 & -2.8 & 14 & $125-180$ & 0.58 & 0.70 & 2.8 & 3 & 479 & 304 & 111 & $897 \pm 34$ & $\begin{array}{r}18 / \\
18\end{array}$ & 15.3 & $52.1 \pm 6.9$ & $58 \pm 8$ \\
\hline \multicolumn{17}{|c|}{ Hadera-1 (SDC1) } \\
\hline HAD-33 & $\mathrm{F} 2$ & 0.4 & 17 & $125-180$ & 0.42 & 0.53 & 1.96 & 2 & $337 \pm 23$ & $214 \pm 13$ & $91 \pm 4$ & $644 \pm 27$ & $\begin{array}{r}13 / \\
14\end{array}$ & 24.2 & $45.8 \pm 11.2$ & $71 \pm 18$ \\
\hline
\end{tabular}


at the time of deposition. The ages are in stratigraphic order within errors, and are consistent within each unit (Fig. 4).

\section{Results}

The sedimentary sequence of the Alexander-Hadera lowland (Fig. $1 \mathrm{c}$ and $\mathrm{d}$ ) consists of five Units (F1-F5), which unconformably overlie the basal unit (Fig. 3). The lithological classification of each unit was obtained through integration of the morphological and sedimentological database. Correlation between units was based on morphological features, thickness, elevations, litho-stratigraphical relations, sedimentological and petrophysical similarities:

\subsection{Basal unit (BU)}

The top $0.5 \mathrm{~m}$ of the basal unit of the sequence was reached in Boreholes SDC4, SY5 and ALX4 (Figs. 1, 3a and c). The upper parts of this unit, whose elevations range from -8.3 to +4.8 relative to the Israel Land Survey Datum (mILSD), are characterized as indurated-brittle cemented sand, while it is identified colour ranges from light reddish grey to dull yellow orange. The unit is dated by OSL in Core SDC4 to $130 \pm 31 \mathrm{ka}$ (Table 1; Fig. 3a).

Samples from Boreholes SDC4 and SY5, retrieved $5 \mathrm{~cm}$ beneath the unit's surface, were examined in thin sections. Samples display well sorted, sub-angular to sub-rounded quartz grains coated by brownish micrite carbonate, while pore space is also filled by micrite. Shell fragments, benthic foraminifera (Ammonia parkinsoniana, Miliolid) and red algae (Amphiroa sp.: Appendix 1) were found solely in Borehole SY5. Based on the micromorphology of the quartz grains and the lack of substantial marine microfauna remains, this basal unit is interpreted as the calcareous sandstone aeolianite surface.

A tentative interpretation (due to sparse spatial sampling) of the buried calcareous sandstone surface (basal unit) reveals two depressions (Fig. 2). The northern one, near N. Hadera, covers an area of $3.4 \mathrm{~km}^{2}$, and consists of three $6 \mathrm{~km}$-long N-S sub-basins parallel to the shoreline. The basins range from +10 to $-10 \mathrm{mILSD}$, and stretch up to $1.3 \mathrm{~km}$ inland from the present shoreline. The southern basin, adjacent to N. Alexander, covers an area of $1.4 \mathrm{~km}^{2}$, and is an oval depression with its long axis oriented NE-SW. It ranges from elevations of +14 to $-6 \mathrm{mILSD}$, and stretches up to $1.4 \mathrm{~km}$ inland from the present shoreline.

\subsection{Unit F1}

Overlying the Basal Unit is Unit F1, identified in Boreholes SDC4, ALX4 and SY5, with the texture of a sandy loam, with a thickness ranging from 0.4 to $0.8 \mathrm{~m}$ (Fig. 3). The surface elevation ranges from -7.5 to +5.3 mILSD, and is characterized as a sediment

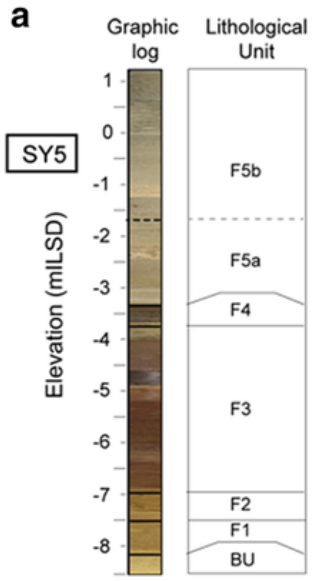

SDC4
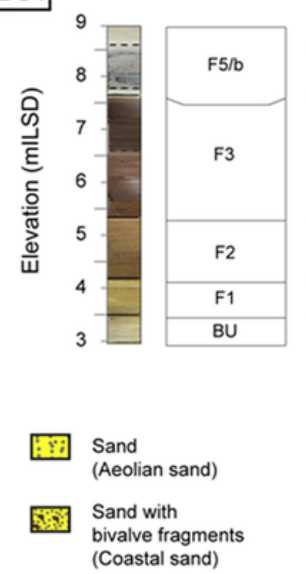
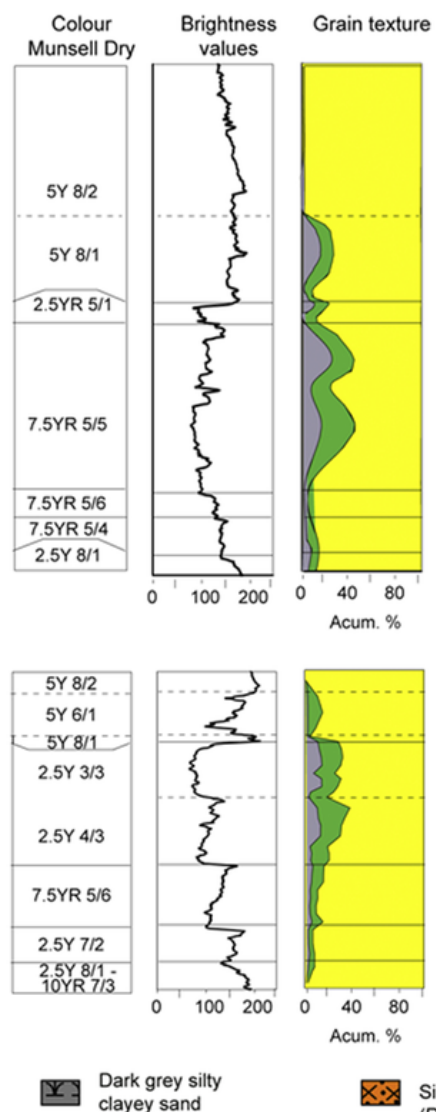

Dark grey silty clayey sand (Wetland)

B.w. Brown silty clayey sand (Brown Palaeosol)
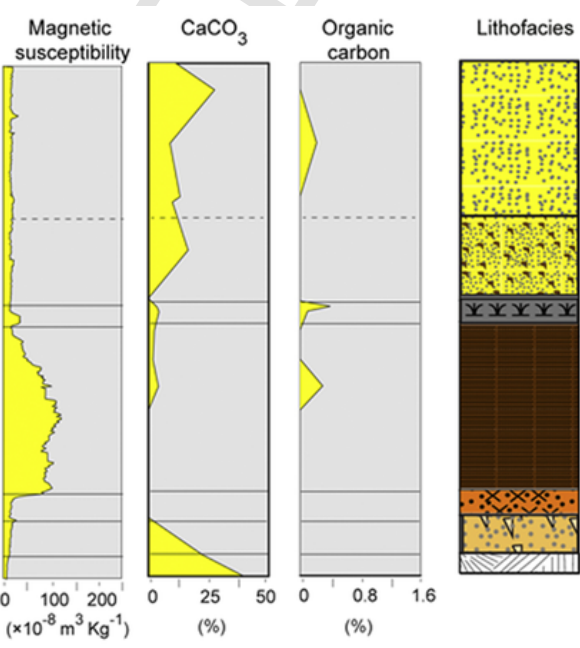

Ages

(ka)
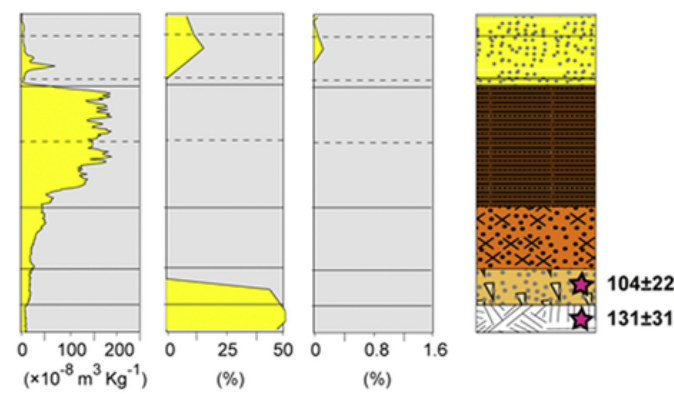

Silty sand
(Red Palaeosol)

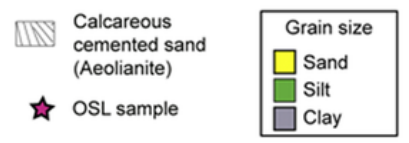

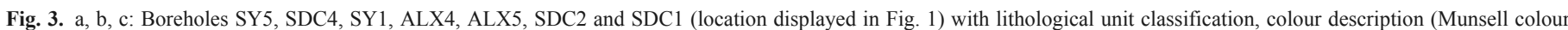

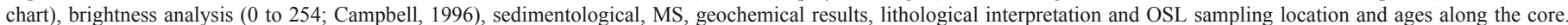

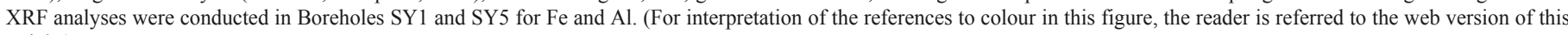
article.) 

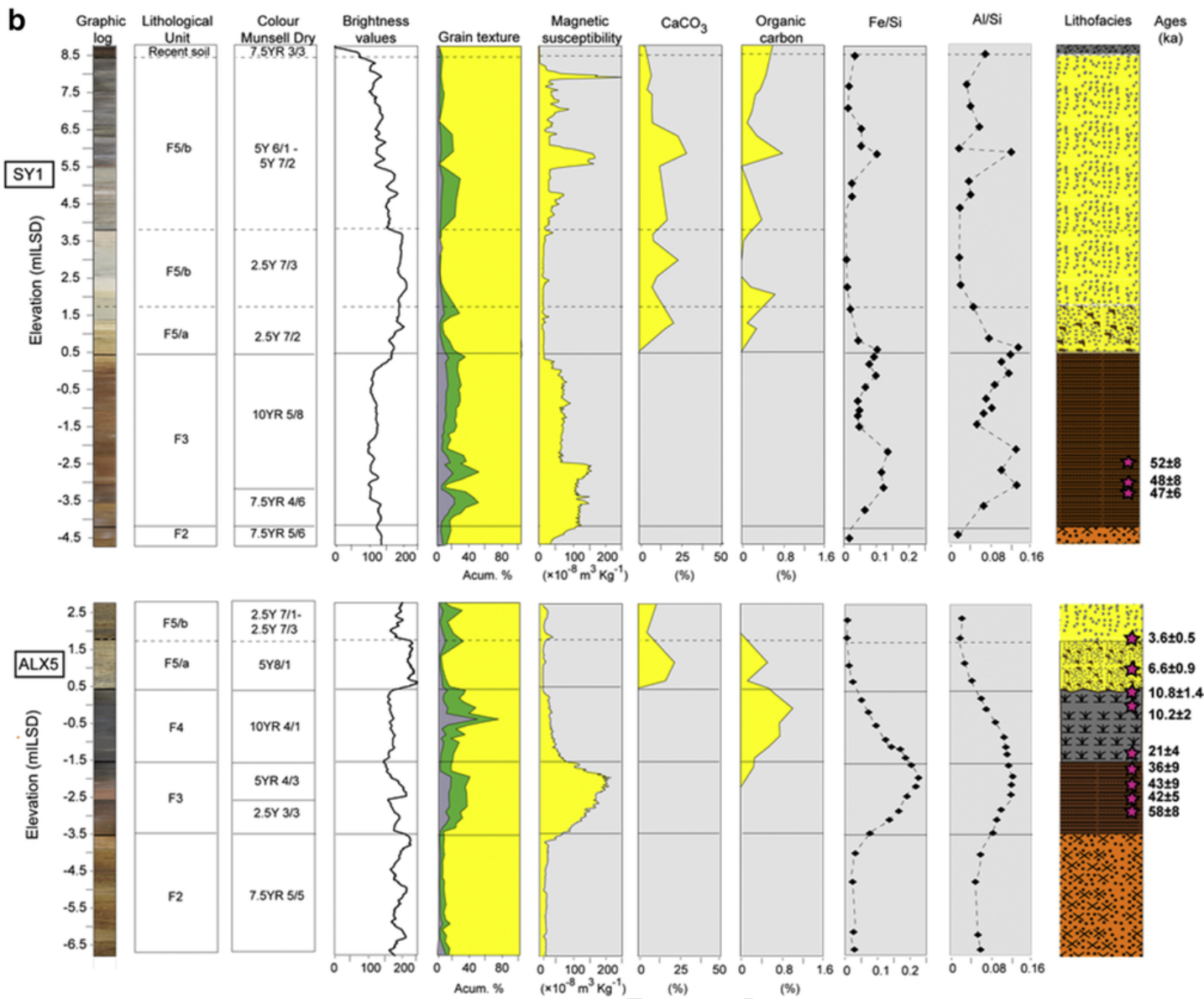

Fig. 3. (Continued)

with irregularly-shaped hard calcareous cemented sand pebbles. The size and abundance of the pebbles decreases upward from $1 \mathrm{~cm}$, and they are absent at the top of the unit. Colour ranges from dull brown to light orange. F1 is defined as an Orange Palaeosol unit containing no microfauna or pollen, and is OSL-dated in Core SDC4 to $104 \pm 22 \mathrm{ka}$ (Table 1; Fig. 3).

\subsection{Unit F2}

Unit F2 lies conformably on Unit F1 (seen in Boreholes SDC4 and SY5: Fig. 3). Its thickness varies from 1 to $3.5 \mathrm{~m}$, while surface elevations range from -4.3 to $+5.1 \mathrm{mILSD}$. Colour ranges from light reddish brown to bright brown, while grain texture becomes finer upwards, and ranges between loamy sand and sandy loam. Elemental analyses show relatively low concentrations of $\mathrm{Fe}$ and $\mathrm{Al}$, which increase toward the top of the unit. These concentration variations correlate with the changing MS values silt and clay content (Fig. 3b). F2, which is defined as the Red Palaeosol unit, contains no microfauna or pollen. This unit is OSL-dated in Core SDC1 to $71 \pm 18 \mathrm{ka}$ (Table 1; Fig. 3).

\subsection{Unit F3}

Unit F3, which occurs in all the boreholes studied, conformably overlies Unit F2 (Fig. 3). Its thickness varies from 1.8 to $4.5 \mathrm{~m}$, while its surface elevations range from -4 to +7.8 mILSD. Grain texture and colour range between sandy clayey loam and sandy loam and dark reddish brown to brown respectively. Elemental analysis shows relatively high concentrations of $\mathrm{Fe}$ and $\mathrm{Al}$, which again correlate with the fluctuating MS values and silt and clay content (Fig. 3b). F3 contains no microfauna or pollen, and is interpreted as a Brown Palaeosol unit. Its age is constrained by seven samples from two cores ranging from $58 \pm 8$ to $36 \pm 9 \mathrm{ka}$ (Table 1 ; Fig. $3 \mathrm{~b}$ ).

\subsection{Unit F4}

Unit F4 conformably overlies the Unit F3 in Boreholes SY5 and ALX5 (Fig. 3), while in Borehole ALX4 it is situated in between two lithofacies of the Brown Palaeosol unit. The unit thickness varies from 0.5 to $2 \mathrm{~m}$, while its surface elevations range from -3.4 to +7 mILSD. The unit's grain texture ranges between clay and sandy clay loam, while colour ranges between yellowish-grey and brownish-grey. Elemental analysis conducted in Borehole ALX5 shows a decreasing trend in concentrations of $\mathrm{Fe}$ and $\mathrm{Al}$ compared to $\mathrm{F} 3$, which are in agreement with MS values (Fig. 3b). F4 is homogeneous, and microfauna and pollen are absent, except for Borehole ALX5, where Zannichellia palustris seeds were identified, suggesting a brackish marsh environment. These characteristics led to the understanding that the F4 dark silty clay was deposited in wetlands. The wetland unit presents three OSL ages: $21 \pm 4,10.2 \pm 2$ and $10.8 \pm 1.4 \mathrm{ka}$, which were sampled from the bottom, $20 \mathrm{~cm}$ below the surface and from the surface of the unit respectively (Table 1; Fig. 3). The ages sampled in the upper part of the unit overlap within measurement errors. 
C
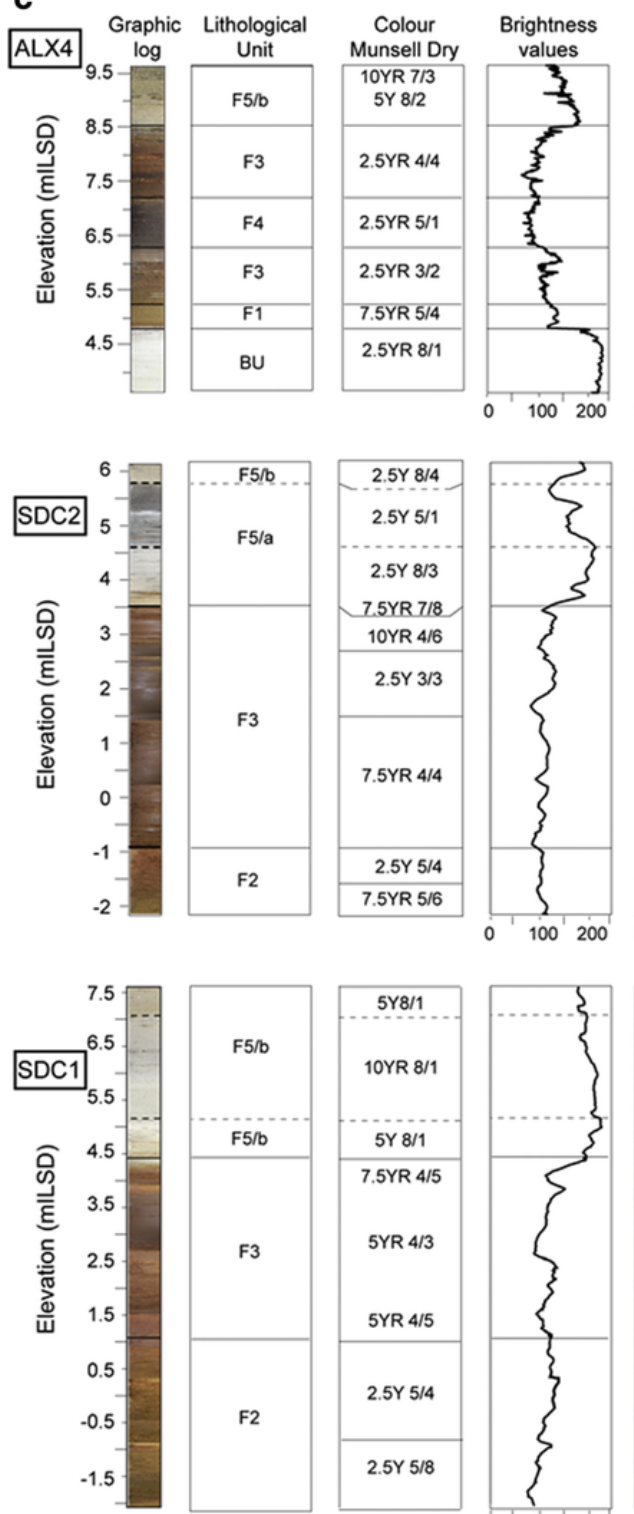
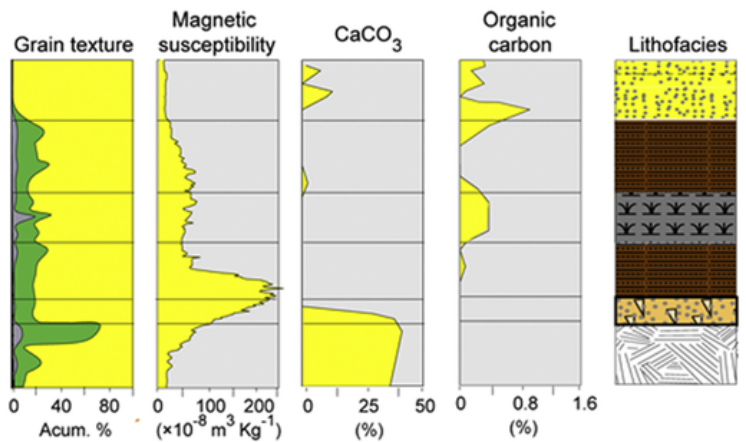

Ages
(ka)
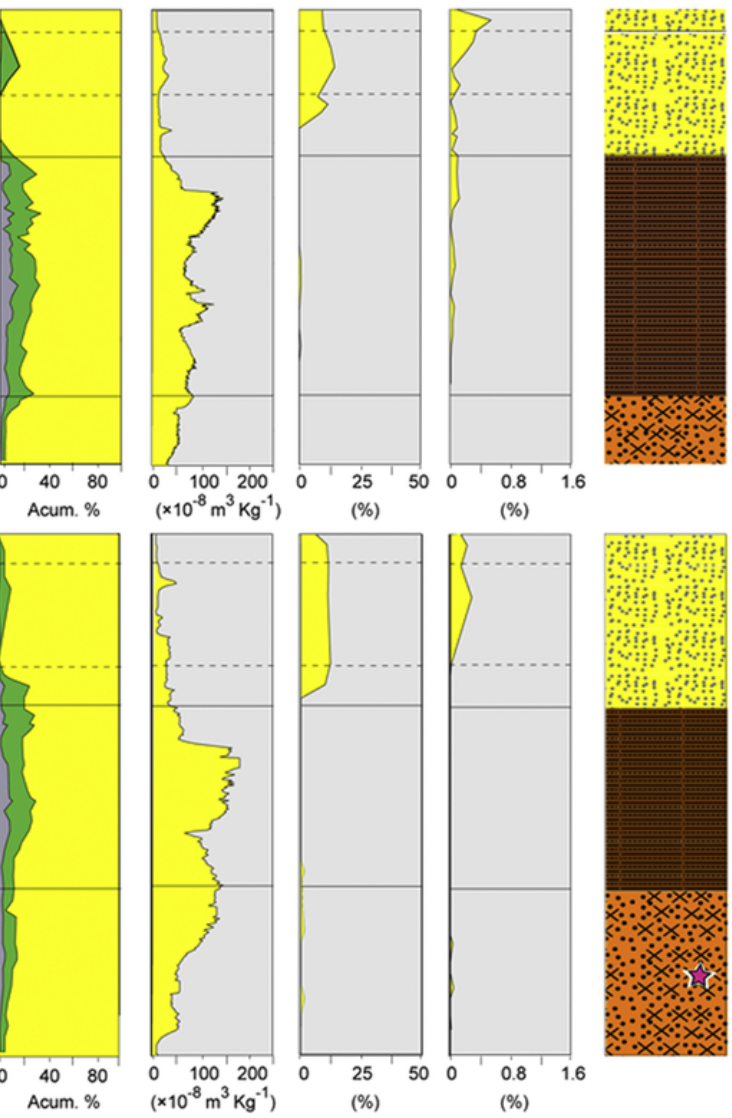

$71 \pm 18$

Fig. 3. (Continued)

\subsection{Unit F5}

The topmost unit (F5) is found in all of the boreholes. F5 overlies Unit F4 in Boreholes ALX5 and SY5, while in SDC1, SDC2, SY1 and ALX4 (Fig. 3) it covers Unit F3. The unit's thickness ranges from 1.3 to $8 \mathrm{~m}$, and its surface elevation ranges from +1.2 to +9.6 mILSD. Unit F5 grain texture ranges from sand to sandy loam, and consists of two identified sub-lithological units, described from bottom to top in Appendix 2.

1. Sub-unit F5a is identified in Boreholes ALX5, SY5 and SY1. The facies colour ranges between yellowish-light grey and greyish-yellow. Elemental analysis shows decreasing concentrations up the section of $\mathrm{Fe}$ and $\mathrm{Al}$ that are generally lower than in Units F3 and F4 (Fig. 3b). The sub-unit elevations range from -2.5 to $+1.2 \mathrm{~m}$ ILSD, accompanied at times by soft cemented sand aggre- gates. Bivalve shell and shell fragments are evident throughout. This relatively poorly sorted sub-unit is identified as beach sand, and was dated by OSL in Core ALX5 to $6.6 \pm 0.9 \mathrm{ka}$ (Table 1; Fig. $3)$.

2. Sub-unit F5b is found in all of the boreholes in the current study, and is partly accompanied by land snails. Its thickness ranges from 0.2 to $7 \mathrm{~m}$, while the facies sediment colour ranges between grey and pale yellow. In Boreholes SY1, SDC2, SDC4 and SDC1 pottery remains are evident in several sediment horizons, while small glass remains (less than $0.5 \mathrm{~cm}$ ), bone fragments, micro-charcoal and lithic fragments of chalk (less than $1 \mathrm{~cm}$ ) also occur in SY1. Elemental analysis conducted in Borehole SY1 shows varying concentrations of $\mathrm{Fe}$ and $\mathrm{Al}$, peaking at $+5.5 \mathrm{mILSD}$, in agreement with MS values (Fig. 3b). This relatively well-sorted sub-unit is interpreted as aeolian sand, and was dated by OSL in Core ALX5 to $3.6 \pm 0.5 \mathrm{ka}$ (Table 1; Fig. 3). 
Unit F5 as a whole is interpreted as an unconsolidated beach aeolian sand unit.

\section{Discussion}

\subsection{Depositional environments of the coastal lowlands}

The Hadera-Alexander sedimentological units consist mainly of quartz sand in various forms: at the base of the sequence as a lithified calcareous sandstone, while the overlying unconsolidated units have undergone pedogenesis, forming loams of various types. These units have been covered since the Mid-Holocene by windblown sand (Fig. $5 \mathrm{a}$ and d; Roskin et al., 2015). Based on these units, four depositional environments - terrestrial (soils), wetland (clay loam), beach (sand) and aeolian - were identified:

1. Terrestrial - These units include the three palaeosols F1, F2 and F3, barren of fauna and pollen, consisting of orange to brown loamy sand to silty clayey sand, with MS values of 50-250 $\left(\times 10^{-8} \mathrm{~m}^{3} \mathrm{~kg}^{-1}\right)$ and low $\mathrm{CaCO}_{3}$ content (Fig. 3). The MS values correlate with the varying silt-clay percent and ferro-magnetic minerals, which point to fine aeolian dust, deposited by rain into the unconsolidated and porous sand profile, driving the pedogenic processes (Gvirtzman and Wieder, 2001; Tsatskin et al., 2008, 2015). $\mathrm{CaCO}_{3}$ content is derived from shell fragments which have been transported inland from the coastal zone/beach. The extent of the pedogenesis process determines the concentration of $\mathrm{CaCO}_{3}$; the longer the process of pedogenesis, the lower is the concentration of $\mathrm{CaCO}_{3}$ as seen in the profile as a result of carbonate dissolution due to leaching (Dan et al., 1968; Yaalon, 1997; Porat et al., 2004; Tsatskin and Ronen, 1999). Based on the high sand content (higher than 70\%) and their associated ages, these palaeosols are presumed to have been formed in the relatively moderate to flat topography of the coastal plain a few hundred metres to several kilometres from the palaeo-coastline when sea level was lower, during most of the last glacial-interglacial period (100-8 ka).

2. Wetland - This unit includes the wetland Facies F4, which consists of organic (about $1 \%$ ) clay to sandy clay loam sediments which are $\mathrm{CaCO}_{3}$-free. Although the unit contains no microfauna or pollen, Zannichellia palustris seeds were identified. These sedimentological properties and the aquatic plant seeds support the interpretation of these sediments being deposited in a brackish marsh environment, while the lack of palaeontological and palynological remains, together with the extended episode of the unit's existence (21-10 ka), suggest prolonged exposure of the sediment to aerial conditions and oxidation.

3. Beach - These sediments include the beach Facies F5a, consisting of poorly-sorted coarse to fine quartz sand (Appendix 2), bivalve shell fragments, allochthonous benthic microfauna and scarce red algae remains, indicating high wave energy of surf zone to the coastline environment. The unit elevations range from -2.5 to +1.2 mILSD.

4. Aeolian - These sediments include sand Facies F5b, and consist of fine well-sorted round quartz sand (Appendix 2), with terrestrial land snail shell fragments, devoid of other fauna. These characteristics suggest sediments that were windblown inland, creating terrestrial sand sheets. Within this facies some horizons include additional features (e.g. potsherds, bone remains and greyish hues). These horizons are probably of anthropogenic origin (Porath, 1975; Roskin et al., 2015); however, further study is required to establish this hypothesis.

\subsection{Coastal lowland and coastal cliff chronostratigraphic correlation}

The coastal lowland sequence which was studied here in detail for the first time can be correlated with the coastal cliff sequence (Fig. 5) located along most of Israel's shore from Ashkelon to the Carmel coast (Fig. 1b). The correlation is based on the lithological description, petro-sedimentological characteristics, accompanying features, and a stratigraphic position comparison of our new OSL ages with published ages (Gvirtzman et al., 1983, 1998; Engelmann et al., 2001; Frechen et al., 2001, 2002; Gvirtzman and Wieder, 2001; Neber, 2002; Porat et al., 2004; Tsatskin et al., 2009; Moshier et al., 2010; Mauz et al., 2013). This correlation suggests that the coastal lowlands are dominated by palaeosol units with little if any aeolianites, while the coastal ridge sections consist primarily of aeolianites interbedded by palaeosols.

The basal unit (BU) of the studied sequence dates to $131 \pm 30 \mathrm{ka}$ (Table 2). Relying on the field description, sedimentological analyses (Fig. 3) and micromorphology (Appendix 1), we propose that this calcareous sandstone unit was deposited in a beach-terrestrial environment. Based on this age range, the stratigraphical position and fea-

Table 2

Age comparison between Alexander-Hadera lowland and generalized coastal cliff sequence.

\begin{tabular}{|c|c|c|c|c|c|}
\hline $\begin{array}{l}\text { Hadera- } \\
\text { Alexander } \\
\text { generalized } \\
\text { lowland } \\
\text { units }\end{array}$ & Lithology & $\begin{array}{l}\text { Lowland } \\
\text { Ages (ka) }\end{array}$ & $\begin{array}{l}\text { Israel's } \\
\text { generalized } \\
\text { coastal cliff } \\
\text { stratigraphic } \\
\text { member }\end{array}$ & Lithology & $\begin{array}{l}\text { Coastal cliff } \\
\text { ages }(\mathrm{ka})\end{array}$ \\
\hline \multirow[t]{3}{*}{ Sand } & $\begin{array}{r}\text { Loose sand } \\
\text { Grey sand }\end{array}$ & $\begin{array}{c}0.12 \pm 0.05^{1} \\
0.86 \pm 0.1^{1}\end{array}$ & Hadera & Loose sand & $\begin{array}{r}0.2 \pm 0.02^{3, \mathrm{a}} \\
5.3 \pm 0.7^{3, \mathrm{a}}\end{array}$ \\
\hline & $\begin{array}{l}\text { Brittle } \\
\text { cemented } \\
\text { sand } \\
\text { aggregates }\end{array}$ & $\begin{array}{c}3.3 \pm 0.5^{1} \\
\mathbf{3 . 6} \pm \mathbf{0 . 5}\end{array}$ & $\begin{array}{l}\text { Ta'arukha } \\
\text { Kurkar Tel- } \\
\text { Aviv }\end{array}$ & $\begin{array}{l}\text { Calcareous } \\
\text { cemented } \\
\text { sand }\end{array}$ & $\begin{array}{l}4.1 \pm 0.3^{3, \mathrm{a}} \\
6.2 \pm 0.7^{3, \mathrm{a}}\end{array}$ \\
\hline & $\begin{array}{l}\text { Sand with } \\
\text { bioclasts }\end{array}$ & $\begin{array}{c}4.3 \pm 0.9 \\
6.6 \pm 0.9\end{array}$ & & $\begin{array}{l}\text { Sand with } \\
\text { land snails }\end{array}$ & $\begin{array}{r}5.7 \pm 0.8^{3, \mathrm{a}} \\
7.9 \pm 0.2^{2}\end{array}$ \\
\hline $\begin{array}{l}\text { Wetland } \\
\text { dark silty } \\
\text { clay }\end{array}$ & $\begin{array}{l}\text { Clay-Sandy } \\
\text { clayey } \\
\text { loam }\end{array}$ & $\begin{array}{c}10.8 \pm 1.4 \\
10.2 \pm 2 \\
21 \pm 4\end{array}$ & $\begin{array}{l}\text { Netanya } \\
\text { palaeosol }\end{array}$ & Sandy loam & $\begin{array}{l}8 \pm 0.4^{4} \\
12 \pm 1^{3, \mathrm{a}} \\
14 \pm 2^{3, \mathrm{a}} \\
19 \pm 2^{3, \mathrm{a}}\end{array}$ \\
\hline $\begin{array}{l}\text { Brown } \\
\text { Palaeosol }\end{array}$ & $\begin{array}{l}\text { Sandy } \\
\text { clayey } \\
\text { loam } \\
\text { Sandy } \\
\text { loam }\end{array}$ & $\begin{array}{c}36 \pm 9 \\
43 \pm 9 \\
52 \pm 8 \\
48 \pm 8 \\
47 \pm 6 \\
58 \pm 8\end{array}$ & $\begin{array}{l}\text { Netanya } \\
\text { palaeosol }\end{array}$ & $\begin{array}{l}\text { Sandy } \\
\text { clayey } \\
\text { loam }\end{array}$ & $\begin{array}{l}33 \pm 3^{3, \mathrm{a}} \\
51 \pm 9^{3, \mathrm{a}} \\
56 \pm 5^{3, \mathrm{a}}\end{array}$ \\
\hline \multirow[t]{2}{*}{$\begin{array}{l}\text { Red } \\
\text { Palaeosol }\end{array}$} & & $71 \pm 18$ & Givat Olga & $\begin{array}{l}\text { Calcareous } \\
\text { cemented } \\
\text { sand }\end{array}$ & $\begin{array}{c}50 \pm 4^{3, \mathrm{a}} \\
56 \pm 4^{2}\end{array}$ \\
\hline & $\begin{array}{l}\text { Palaeosol } \\
\text { Calcareous } \\
\text { cemented } \\
\text { sand }\end{array}$ & & & & $\begin{array}{l}55 \pm 5^{3, a} \\
74 \pm 8^{4}\end{array}$ \\
\hline $\begin{array}{l}\text { Orange } \\
\text { Palaeosol }\end{array}$ & $\begin{array}{l}\text { Sandy loam } \\
\text { with } \\
\text { calcareous } \\
\text { nodules }\end{array}$ & $\begin{array}{c}87 \pm 17^{1} \\
92 \pm 18^{I} \\
\mathbf{1 0 4} \pm \mathbf{2 2}\end{array}$ & $\begin{array}{l}\text { Kefar } \\
\text { Vitkin } \\
\text { Palaeosol }\end{array}$ & $\begin{array}{l}\text { Sandy loam } \\
\text { with } \\
\text { calcareous } \\
\text { nodules }\end{array}$ & $\begin{array}{c}80 \pm 5^{3} \\
84 \pm 4^{3}\end{array}$ \\
\hline Aeolianite & $\begin{array}{l}\text { Calcareous } \\
\text { cemented } \\
\text { sand }\end{array}$ & $131 \pm 31$ & $\begin{array}{l}\text { Kurkar } \\
\text { Herzeliyya }\end{array}$ & $\begin{array}{l}\text { Calcareous } \\
\text { cemented } \\
\text { sand }\end{array}$ & $98 \pm 6^{3}$ \\
\hline
\end{tabular}

Ages annotated in Bold were dated in the current study.

References: (1) Roskin et al., 2015 (2) Mauz et al., 2013 (3) Engelmann et al., 2001; Frechen et al., 2001, 2002; Porat et al., 2004 (4) Moshier et al., 2010.

a IRSL ages of K-feldspars. The ages were obtained 15-20 years ago using IR50, and were not corrected for anomalous fading. The true ages could be as much as 20 to $30 \%$ older (Thomsen et al., 2008). 
tures of the units can be correlated with the upper terrestrial facies of Herzliyya kurkar (i.e., $98 \pm 6$ ka; Mauz et al., 2013), which was found at elevations ranging from a few metres above ILSD on the Carmel coast to about -75 mILSD in southern Israel (Fig. 1b; Gvirtzman et al., 1983; Frechen et al., 2004).

Overlying the Herzliyya kurkar is the Orange Palaeosol (F1), dated to about $104 \pm 22 \mathrm{ka}$ (Fig. 3a). A similar facies, with corresponding sedimentological appearances (hue, lithology, grain size, $\mathrm{CaCO}_{3}$ and accompanying irregularly-shaped calcareous cemented sand nodules), has been identified $2 \mathrm{~km}$ south of Borehole SDC4 and dated to $87 \pm 17 \mathrm{ka}$ (Roskin et al., 2015). Based on this age range, the stratigraphical position of the units (Gvirtzman et al., 1983) and features can be correlated with the Kfar Vitkin palaeosol (Gvirtzman et al., 1998; Frechen et al., 2004), which was found at elevations ranging from about +8 mILSD to about -70 mILSD (Fig. 1b; Gvirtzman et al., 1998; Frechen et al., 2004; Tsatskin et al., 2009). There are differences between the two units, with F1 having lower silt and clay concentrations and lower MS values than the Kfar Vitkin palaeosol (Mauz et al., 2013). These sedimentological differences are proposed to be a result of relief differences and slope angle variations between the two areas, leading to lateral erosion of sediments in the sloping areas and re-deposition in the depression (Dan et al., 1968; Yaalon, 1997; Tsatskin et al., 2009).

The Orange Palaeosol unit is covered by the Red Palaeosol (F2), which is dated to about $71 \pm 18 \mathrm{ka}$ (Fig. 3c). During the depositional time of the Red Palaeosol parent material, from 80 to $55 \mathrm{ka}$, sand was deposited on the coastal plain of Israel in a thickness ranging from 2 to $40 \mathrm{~m}$ (Zilberman et al., 2007; Roskin et al., 2013), forming dunes and sand sheet complexes. Since stream energies were greater during periods of low sea levels, mainly due to higher gradients and incisions (Suter and Berryhill, 1985; Anderson et al., 1996; Blum and Tōrnqvist, 2000 and ref. therein), the streams limited sand deposition in their channels, consequently transporting the sand back to the coastline where it was deposited. The sand removal from the stream outlets and dune build-up over the rest of the area led to the formation of the lowlands (Fig. 1c and d). Moreover, the synchronous deposition of the dune-sand sheet complex (up to $40 \mathrm{~m}$ ) and the slow sand sheet accumulation in the coastal lowland (up to $4 \mathrm{~m}$ ) led to the concurrent development of the coastal ridges Givat Olga Member (aeolianites interbedded by Nahsholim Palaeosol; Gvirtzman et al., 1983, 1998) and lowland Red Palaeosol (Figs. 5 and 6; Frechen et al., 2002; Mauz et al., 2013).

The Red Palaeosol is overlain by a dark reddish-brown to brown unit with sandy clayey loam to sandy loam grain texture (F3). This Brown Palaeosol consists of high $\mathrm{Fe}$ and $\mathrm{Al}$ concentrations, which are in agreement with fluctuating MS values, and is dated to between $58 \pm 8$ and $36 \pm 9$ ka (Figs. 3 and 4). The carbonate percentage, particle size, MS and chronology of the Brown Palaeosol are comparable to the lower coastal cliff Netanya palaeosol sub-unit (Fig. 5; Gvirtzman and Wieder, 2001). The upper sub-units of the Netanya palaeosol are dated from 12 to $8 \mathrm{ka}$ at varying elevations ranging from +10 mILSD to about +40 mILSD in an N-S section from the Sharon coast to Ashkelon in the south (Figs. 1b and 5; Gvirtzman et al., 1983, 1998; Frechen et al., 2002; Porat et al., 2004; Mauz et al., 2013). Even though the top of the lowland Netanya palaeosol was not dated in this study (Appendix 3) the unit's surface was dated in a similar geomorphic location south of Rishon-Lezion (Fig. 1b) to $8.6 \pm 2.5$ ka (Roskin et al., 2016).

In several boreholes adjacent to the stream paths, a dark silty-clay deposit (F4) was identified covering the Brown Palaeosol. This wetland facies, dated from $21 \pm 4$ to $10 \pm 2 \mathrm{ka}$, was also identified along the Carmel coast (Kadosh et al., 2004; Cohen-Seffer et al., 2005;
Sivan et al., 2011 among others) adjacent to stream systems but was not detected on the higher coastal ridge sequence (Fig. 4).

The topmost unit identified in the lowlands consists of four sandy units deposited from 6.6 to 0.1 ka (Fig. 6; Roskin et al., 2015) which correspond closely to three aeolian units deposited on the coastal ridges (6.2 to $0.1 \mathrm{ka})$ : Hadera; Ta'arukha sand; and the Tel-Aviv kurkar (Gvirtzman et al., 1983).

\subsection{Global to regional-scale triggering forces influencing the formation of the coastal stratigraphy}

The reconstructed chronostratigraphy for the lowlands and coastal cliff can be linked to both global and regional environmental proxies, in order to highlight the triggering and driving forces that shaped the Israel coastal evolution over the last $110 \mathrm{ka}$. In the following sections the contribution of global sea-level, together with regional climate, is discussed.

\subsubsection{Low sea levels and their controls on sedimentation gaps}

From about 110 ka to the Middle Holocene, the continental shelf was partly-fully exposed due to lower than present sea levels (Fig. 6). The common parent material of the last glacial-interglacial coastal sequence of Israel and the relatively continuous ages (Figs. 4 and 5) suggest that the longshore transport of sand from the Nile Delta to the coastal zone was fairly continuous during most of the period studied. Nevertheless, both the lowland and coastal cliff sequences highlight a possible depositional time gap in the Netanya palaeosol from about 33 to $12 \mathrm{ka}$ (Figs. 5 and 6). The disruption in sand accumulation is supported by various studies from across the southern (Zilberman et al., 2007; Roskin et al., 2011a), central (Gvirtzman et al., 1998; Gvirtzman and Wieder, 2001; Sivan and Porat, 2004) and northern (Zviely et al., 2006; Elyashiv, 2013) Israeli coastal plain, in which only a single age of $19 \pm 2$ ka was obtained by Frechen et al. (2001), sampled from a coastal ridge in central Israel. Global eustatic sea level curves (Spratt and Lisiecki, 2015), regional eustatic sea level proxy records (Anzidei et al., 2011; Rohling et al., 2014), local RSL data (Sivan et al., 2001) and erosive unconformity from subsurface profiles (Schattner et al., $2010,2015)$ suggest that this gap is associated with the LGM lowstand (33 to $15 \mathrm{ka}$ ), and then from 15 to $12 \mathrm{ka}$ during the rapid RSL rise.

During the lowstand, sea level ranged from -85 to -130 mILSD, and the shoreline was situated below the shelf-break (Figs. 6i and 7e). The shelf-break curvature - exceeding $1^{\circ}$ - (Almagor et al., 2000) and its ridged surface (Schattner et al., 2010, 2015) served as a further barrier to easterly aeolian transportation of sand (Posamentier et al., 1992; Mauz et al., 2013; Shtienberg et al., 2016). A depositional gap of aeolian sediments during lower sea level phases has been described for other Mediterranean coastal areas, and even beyond it. These included Egypt (El-Asmar, 1994; El-Asmar and Wood, 2000), Tunisia (Mauz et al., 2009; Elmejdoub et al., 2011) southern Spain (Zazo et al., 2008) and the Canary Islands (von Suchodoletz, et al., 2010), occurring from $70 \mathrm{ka}$ in the Mediterranean and from $30 \mathrm{ka}$ in the Canary Islands to Mid-Holocene. The longer hiatuses in sedimentation documented in the northern coasts of Egypt (shelf-break curvature $\left.0.15^{\circ}\right)$ and northern Tunisia $\left(0.1^{\circ}\right)$ are presumed to be the result of the shallower coastal profile, compared to Israel's shelf bathymetry $\left(0.5^{\circ}\right)$ (Almagor et al., 2000; Sade et al., 2006; Amante and Eakins, 2009).

At the end of the LGM (about 20 to $19 \mathrm{ka}$ ), sea level rose rapidly, reaching $-85 \mathrm{~m}$ by $15 \mathrm{ka}$ (Fig. 6h; Lambeck and Purcell, 2005). As a result of the fast transgression (Waelbroeck et al., 2002; Rohling et al., 2014; Spratt and Lisiecki 2015), accommodation space outpaced 


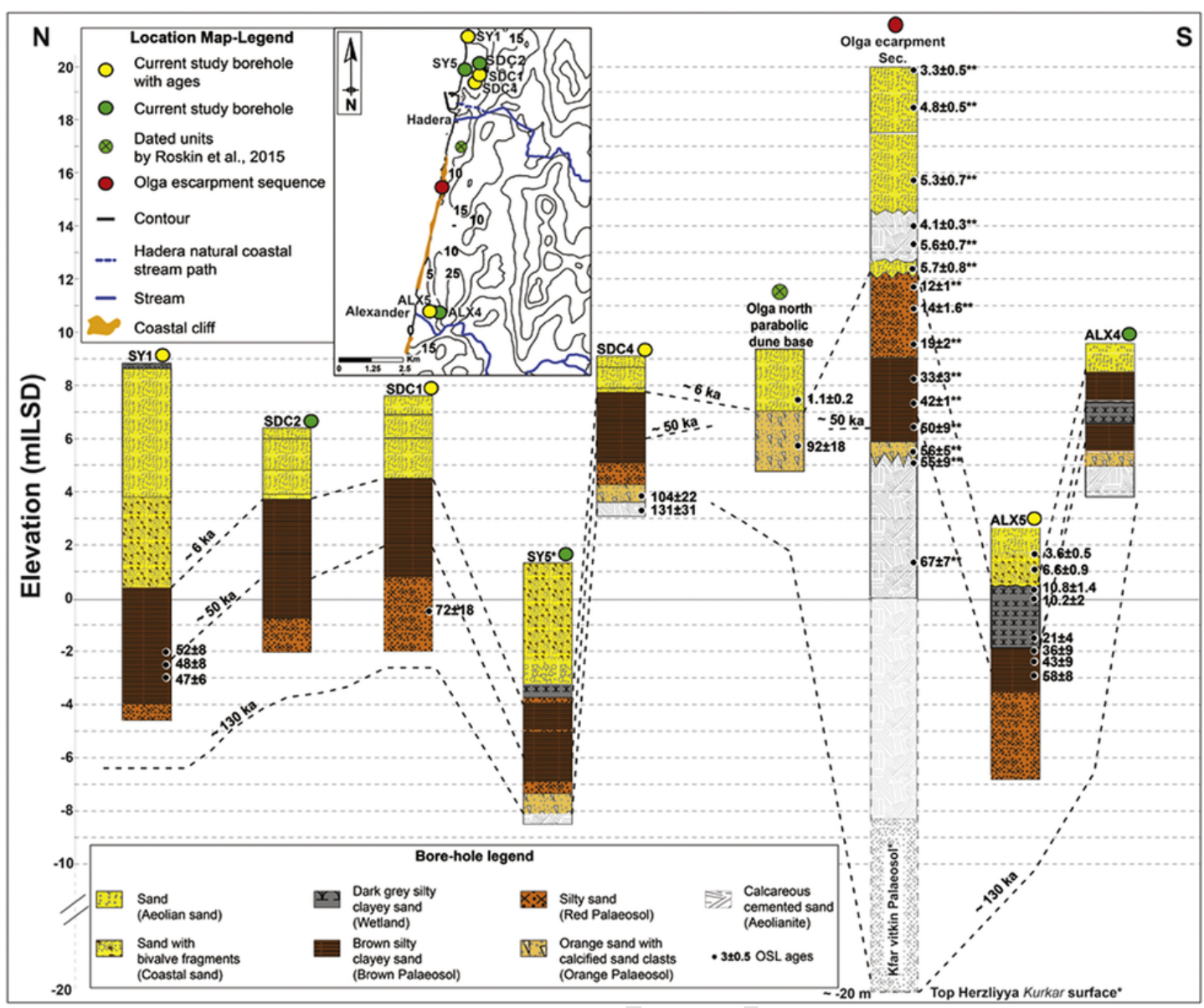

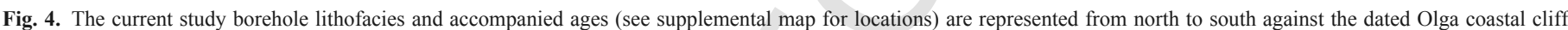

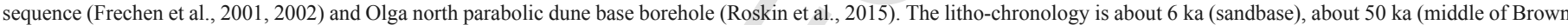

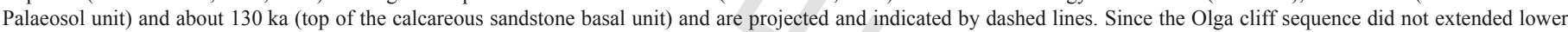

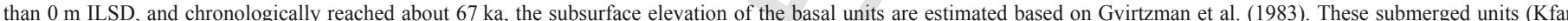

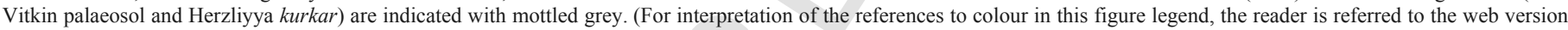
of this article.)

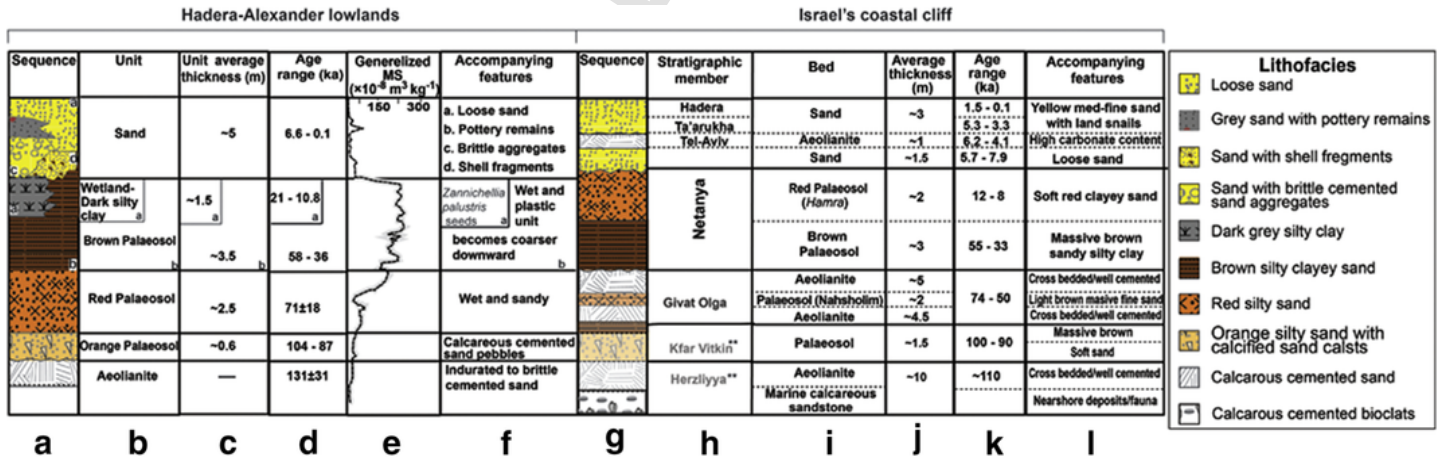

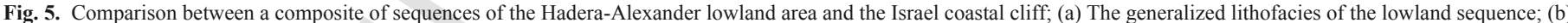

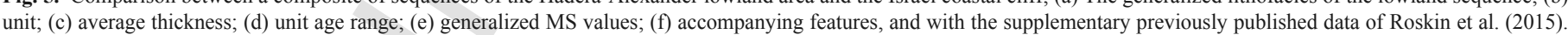

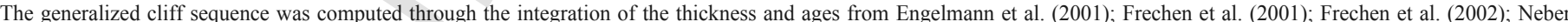

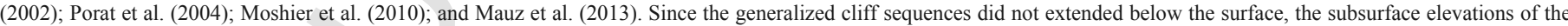

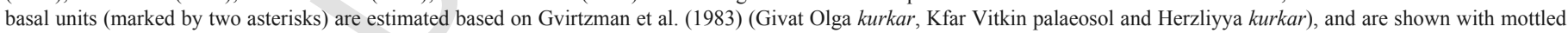
grey symbols; (g) The generalized lithofacies of the coastal cliff sequence; (h) stratigraphic member; (i) bed; (j) average thickness; (k) unit age range; (l) accompanying features. 


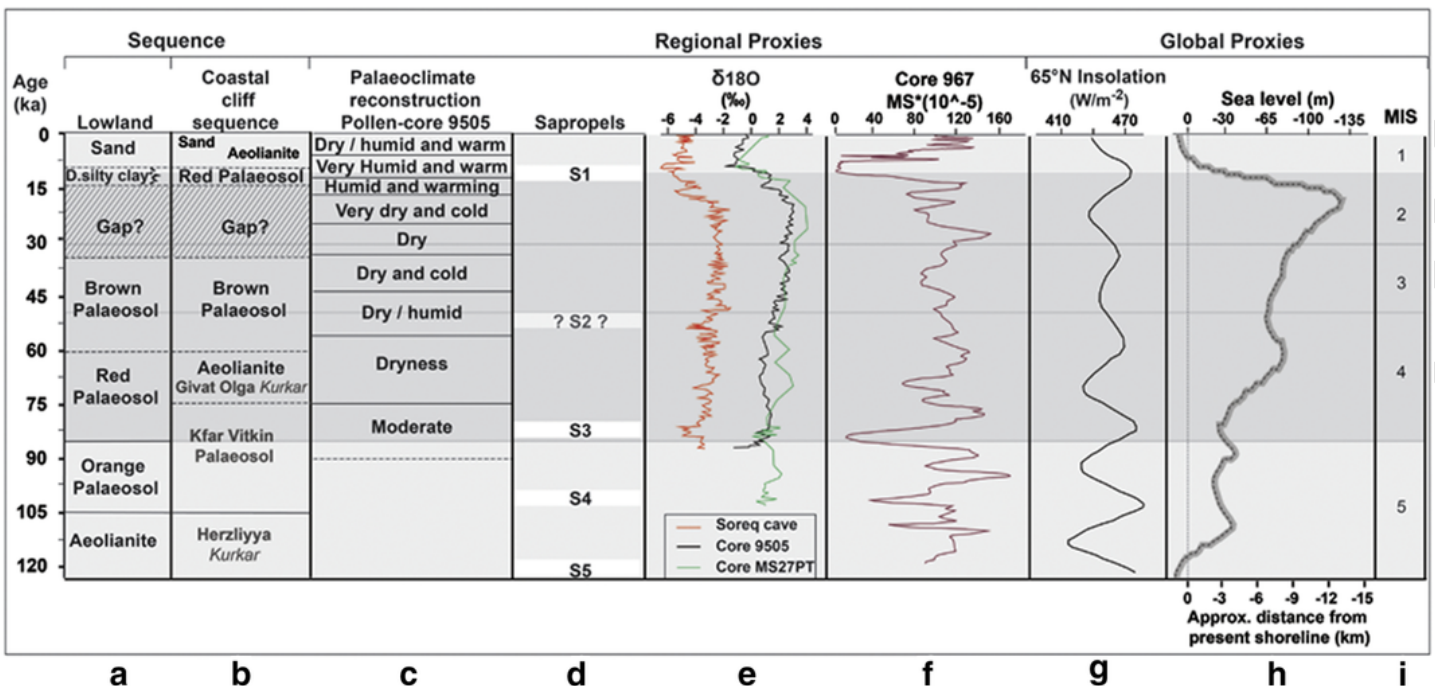

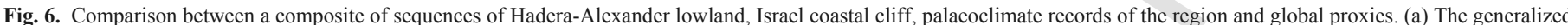

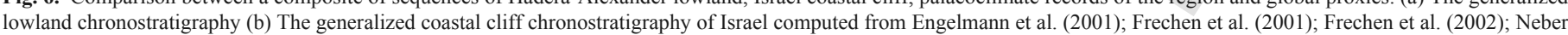

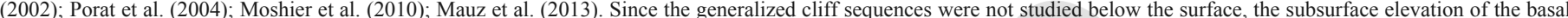

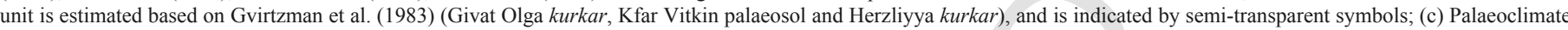

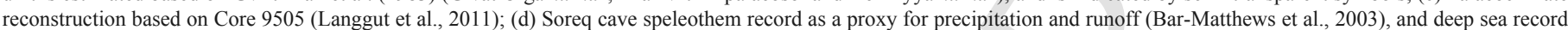

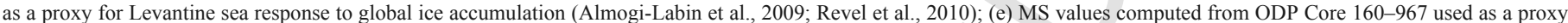

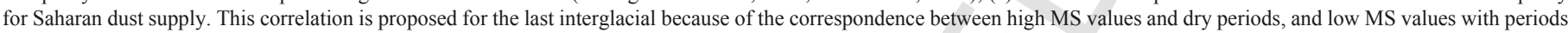

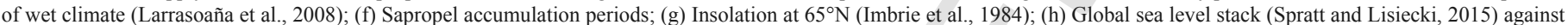
approximated distance from present shoreline; (i)Marine Isotope stages.

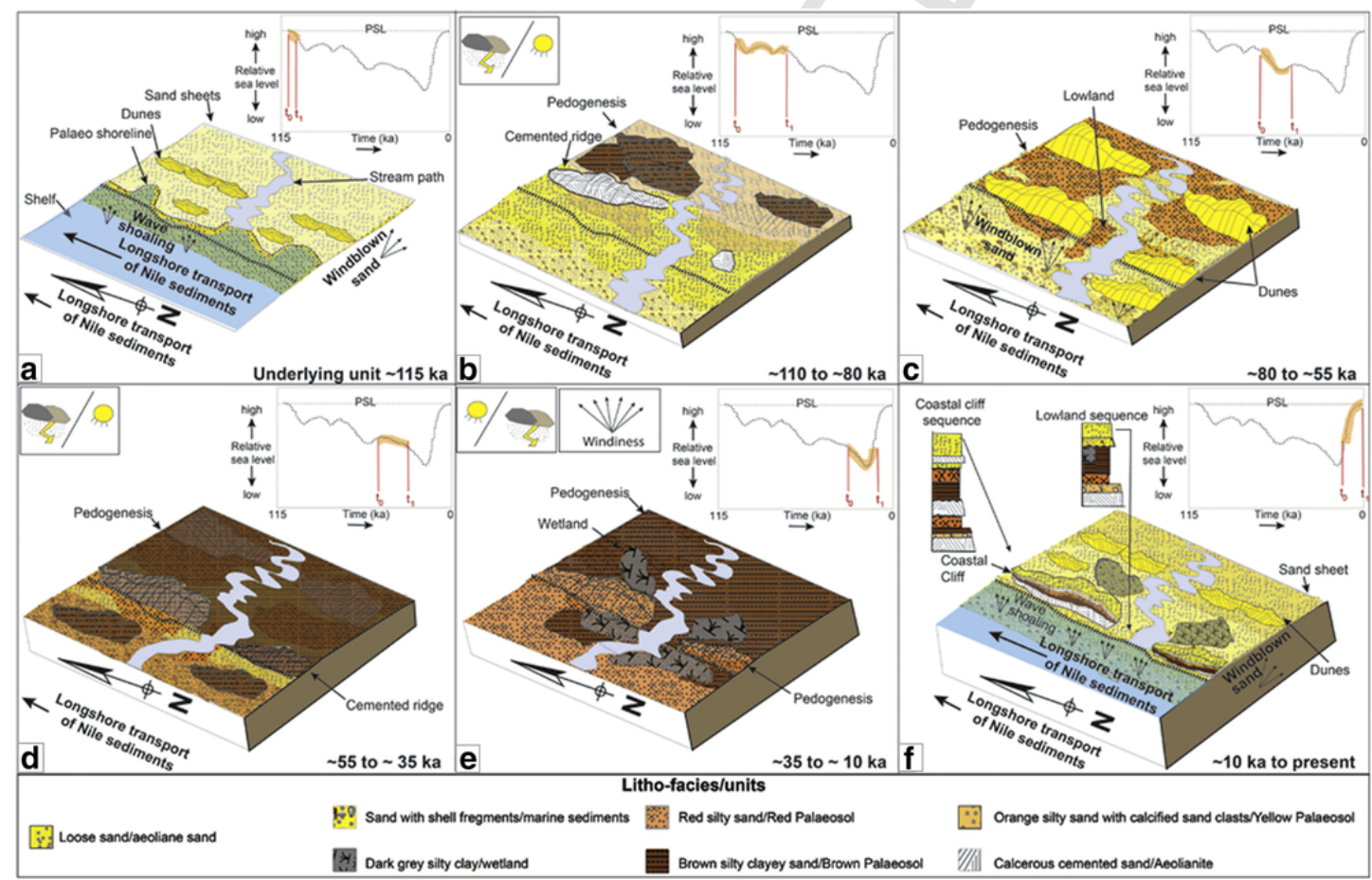

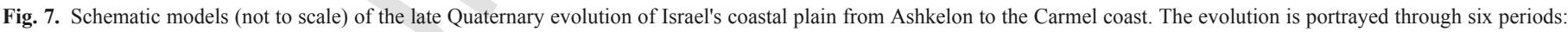

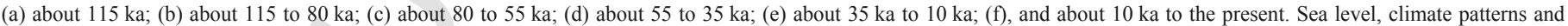
sediment transport are also shown in their appropriate period. The present shoreline location is shown as a thick dotted line. 
sediment supply, hindering sand deposition on the coastal plain until $12 \mathrm{ka}$.

\subsubsection{Regional processes affecting pedogenesis}

The environment of deposition and post-depositional changes on Israel's coastal plain have inevitably been affected by climate change. Such regional processes are identified in the sediments of both the lowland coastal plain and the coastal cliffs. These sediments pedogenised into Netanya palaeosol across most of Israel's coastal plain (Fig. 5; Gvirtzman et al., 1983; Gvirtzman and Wieder, 2001; Neber, 2002; Tsatskin et al., 2008). The MS values $\left(80-250 \times 10^{-8} \mathrm{~m}^{3} \mathrm{~kg}^{-1}\right)$, which are high compared to the other units found in the Quaternary sequence, and the red-dark brown hues are the result of continuous enrichment by aeolian dust and illuviation of the clay's associated magnetic iron-rich minerals (Fig. 3b), e.g. smectite (Dan et al., 1968). These petro-sedimentological characteristics are temporally associated with regional climate proxies that include lower $\delta^{18} \mathrm{O}$ values and oak types (Fig. 6c to f; Bar-Matthews et al., 2003; Revel et al., Langgut et al., 2011), suggesting relatively wetter climatic conditions during pedogenesis (Yaalon; 1997; Tsatskin and Ronen, 1999; Gvirtzman and Wieder, 2001). These wetter climatic conditions, coaeval with Sapropel S2, also enhanced pedogenesis across the Canary Islands, which were influenced by fluctuations in the Saharan dust supply, and are reflected in changes in environmental conditions in the northwest African region (Bozzano et al., 2002). For example, a clay-rich, brown-red palaeosol with high MS values was formed throughout Lanzarote, dated from 55 to $30 \mathrm{ka}$ (von Suchodoletz et al., 2010).

\subsection{Evolution of the coastal plain of israel during the Late Quaternary}

During MIS5e, sea level was 1 to $7 \mathrm{~m}$ higher than at present (Fig. 6i; Galili et al., 2007; Hearty et al., 2007; Kopp et al., 2009, 2013; Rohling et al., 2014; Dutton et al., 2015; Spratt and Lisiecki, 2015; Sivan et al., 2016). Based on the reconstructed topography of the Late Pleistocene calcareous sandstone surface (Fig. 2), together with Boreholes Caesarea IEC1; Hadera 1, Kfar Vitkin T/48/0 (Fig. 1c and d), and the elevation of the Herzliyya kurkar surface along Israel's coastal plain (Gvirtzman et al., 1983), we propose that over this period inland flooding occurred, creating an irregular coastline with estuaries, bays and headlands (Fig. 7a). Based on a simplified reconstruction combining sea level data from Spratt and Lisiecki (2015) and modern-day bathymetry of the Israeli continental shelf (Hall, 1994), the approximate distance from present shoreline is shown in Fig. 6h from $115 \mathrm{ka}$ onward.

From about 110 to $80 \mathrm{ka}$, sea level fluctuated by magnitudes of about $\pm 25 \mathrm{~m}$, while the shoreline was located up to $5 \mathrm{~km}$ westward (Fig. 6h). Nilotic sand, which continued to be deposited on the palaeo-shores (present day offshore) of Israel, was windblown inland, dispersing on the palaeo-coastal plain. The aeolian sand covered the basal aeolianite (BU) as a thin (about 1 to $2 \mathrm{~m}$ thick) sand sheet (Fig. 7b), in some areas leaving the surface exposed for long periods. The sedimentological characteristics of the Orange palaeosol, consisting of light orange sandy loam with hard calcareous cemented irregularly-shaped sand pebbles, the size and abundance of which decrease from the bottom to the top of the unit, were identified in the Hadera-Alexander lowland (Fig. 1c, d) and on the Carmel coast (Frechen et al., 2004; Tsatskin et al., 2009; Roskin et al., 2015). These characteristics suggest that the basal aeolianite surface (BU) partly weathered back to its parent material ( $\mathrm{C}$ horizon). The weathered aeolianite material and newly deposited Nilotic quartz sand pe- dogenised to form Kfar Vitkin Palaeosol. In the Carmel coast this unit has a red-dark red colour, high MS values and higher silt and clay contents (Fig. 3; Frechen et al., 2004; Tsatskin et al., 2009; Mauz et al., 2013). The ages of the unit correlate to similar dark red silty clayey palaeosols that formed on the northern coasts of Egypt and Tunisia (El-Asmar and Wood, 2000; Elmejdoub et al., 2011, who propose their connection with the wetter climate of Sapropel 3) (Fig. 6).

Between 80 and $55 \mathrm{ka}$, sand accumulated across the coastal plain, covering the Kfar Vitkin Palaeosol (Fig. 7c). Deposition was limited close to the stream outlets, eventually resulting in sand sheets only $2 \mathrm{~m}$ thick. Following stabilization at about $55 \mathrm{ka}$, the sand unit close to the streams slowly pedogenised into the Red Palaeosol (Figs. 5, 6 and 7c). The pedogenesis process was controlled by the interaction of dust accumulations and precipitation. The source of the dust that accumulated on the coastal plain of Israel was either solely or jointly supplied by the wide exposed shelf, Sahara deserts (Enzel et al., 2008), or the north of the Sinai-Negev dune field (Ben-David, 2003; Crouvi et al., 2012). The post-depositional pedogenic process took place during wetter periods, enabling hydrolytic weathering of silicate minerals and leaching of dispersed clay minerals in the soil profile. The process ended when sand deposition exceeded the pedogenic process, resulting in the burial of the soil, and leading to a new pedogenetic cycle (Yaalon, 1967, 1997; Tsatskin and Ronen, 1999; Gvirtzman and Wieder, 2001; Mauz et al., 2013). Due to the low to moderate silty-clay content, the light hues contain relatively low concentrations of $\mathrm{Fe}, \mathrm{Al}$, and the MS values of the Red Palaeosol. This unit is interpreted as a moderately developed palaeosol (Fig. 3b). We propose that the Red Palaeosol is the outcome of the relatively dry conditions which prevailed between 80 and $55 \mathrm{ka}$, in light of the relatively constant aeolian dust supply during the formation of the three lowland palaeosol units from 80 to $25 \mathrm{ka}$ (Fig. 6c-e; Cheddadi and Rossignol-Strick, 1995; Larrasoaña et al., 2008). In other locations, distant from the stream paths, dune-sand sheet complexes up to $40 \mathrm{~m}$ thick were deposited, eventually forming the lower exposed units of the present-day shore-parallel ridges (i.e. Givat Olga member; Figs. 5 and 7c; Gvirtzman et al., 1998; Engelmann et al., 2001; Mauz et al., 2013).

The regressing sea level reached about -65 mILSD by $55 \mathrm{ka}$, and from about 55 to $35 \mathrm{ka}$ it fluctuated by about $\pm 10 \mathrm{~m}$ (Fig. 6h; Waelbroeck et al., 2002; Rohling et al., 2014). During this time of RSL stability, windblown quartz sediments covered Israel's palaeo-coastal plain (Fig. 7d) by an average thickness of about $3.5 \mathrm{~m}$ (Fig. 5a). Based on a correlation conducted across most of Israel's coastal plain and in two shallow shelf locations (depth shallower than - $40 \mathrm{mILSD}$ ) located offshore, the southern (Ashkelon; Porat et al., 2003) and central (Hadera; Shtienberg et al., 2016) coasts of Israel, it is evident that this sand sheet pedogenised into Netanya Palaeosol (Gvirtzman et al., 1983; Gvirtzman and Wieder, 2001; Neber, 2002; Tsatskin et al., 2008). The sedimentological and petrophysical characteristics of Netanya Palaeosol suggest a unit which is fully pedogenised (Yaalon, 1997; Gvirtzman and Wieder, 2001) along most of the palaeo-coastal plain of Israel. Regional climate proxies indicate that the pedogenesis of the Netanya palaeosol occurred during an alternating relatively wet climate that prevailed from about 55 to $45 \mathrm{ka}$, and dry climate from about 45 to $35 \mathrm{ka}$ (Fig. 6; Cita et al., 1977; Cheddadi and Rossignol-Strick, 1995; Lourens et al., 1996; Revel et al., 2010). These changing climate periods were accompanied by a relatively constant dust accumulation (Enzel et al., 2008), interpreted from the MS values (Fig. 6) of the Ocean Drilling Program ODP 160-976 (see location in Fig. 1b; Larrasoaña et al., 2008). 
A rapid drop in sea level occurred from about $35 \mathrm{ka}$ to $20 \mathrm{ka}$, when sea level fell from about -85 mILSD to a minimum of about -135 mILSD (Rohling et al., 2014), resulting in shoreline migration from about $11 \mathrm{~km}$ to about $14 \mathrm{~km}$ offshore (Fig. $6 \mathrm{~h}$ ). The regressing coastline was accompanied by increased windiness and dry and cold conditions, which continued until about 16 ka (Fig. 6; Bar-Matthews et al., 2003; McGee et al., 2010; Revel et al., 2010; Roskin et al., 2011a, $2011 \mathrm{~b}$ ). Much like the coastal areas of northern Tunisia (Elmejdoub et al., 2011) and the Huelva coast in south-western Spain (Zazo et al., 2005), the low sea level and climate conditions left the coast and exposed shelf sediment starved, inducing an erosional hiatus.

At the end of the LGM, sea level rapidly rose, (Fig. 6h; Waelbroeck et al., 2002; Lambeck and Purcell, 2005; Spratt and Lisiecki 2015), hindering sand deposition on the coastal plain unit until $12 \mathrm{ka}$. A dark-grey silty clay facies was identified adjacent to the streams in the Alexander and Hadera lowlands (Figs. 3 and 7e), indicating wetlands. These wetlands resemble, in their location and age, the wetlands on the coast and the shallow shelf of southern (Porat et al., 2003), central (Neev et al., 1978; Kadosh et al., 2004; Sivan et al., 2011; Shtienberg et al., 2016), and northern (Avnaim-Katav et al., 2012; Elyashiv et al., 2016) Israel. As suggested by Sivan et al. (2011), Elyashiv et al. (2016) and Shtienberg et al. (2016), such units were deposited on the coastal plain as a result of stream overflows affected by rising sea level and a wetter climate, which changed from about $15 \mathrm{ka}$, as a result of the extreme insolation values (Fig. $6 \mathrm{c}$ and d; Bar-Matthews et al., 2003; Revel et al., 2010; Langgut et al., 2011).

During the Pleistocene-Holocene transition, sea level transgression rates slowed (Fig. 6h; Lambeck and Bard, 2000), and the palaeo-shoreline was located about $3 \mathrm{~km}$ offshore of its current position (Fig. 6h). Consequently, sediment transport recommenced from the Nile Delta by the longshore currents and was carried landward by the wind. The depositing sand pedogenized to form the upper sub-units of Netanya Palaeosol identified on the coastal ridges and lowlands, dated from 12 to 8 ka (Fig. 5; Gvirtzman and Wieder, 2001; Porat et al., 2004; Roskin et al., 2016). The earliest documented deposition of the upper, unconsolidated, sand is about $8 \mathrm{ka}$ (Fig. 5; Gvirtzman and Wieder, 2001; Mauz et al., 2013), and is proposed to be the result of two contributing factors: (a) erosion of the Nile Delta as a result of the rising sea levels, consequently increasing the sediment discharge to the Levantine basin (Fig. 6h; Stanley and Warne, 1998; Revel et al., 2010); and (b) closer coastlines and slower sea level rise. The high sediment discharge hypothesis is supported by higher sedimentation rates of $55 \mathrm{~cm} / \mathrm{ka}$ and $110 \mathrm{~cm} / \mathrm{ka}$ calculated from the deep-sea Cores 9505 and MS27PT (Fig. 1a; Revel et al., 2010; Langgut et al., 2011;), respectively, and higher fluxes of up to $180 \mathrm{~cm} /$ $\mathrm{ka}$ in the shallow marine Cores V115, V101, located $1.5 \mathrm{~km}$ seaward from the current shoreline in a water depth of $-30 \mathrm{~m}$ (Fig. 1b; Mor-Federman, 2012). In addition, the shoreline reached about $1.5 \mathrm{~km}$ offshore from its present position (Fig. 6h).

Archaeological observations from the coast confirm that sea level continued to rise during the early stages of the Holocene until about 6-7 ka, when transgression slowed considerably. Then, at about 6 to $4 \mathrm{ka}$, as sea level and the coastline almost reached their present elevation and location (Fig. 6; Sivan et al., 2001, 2004; Anzidei et al., 2011; Toker et al., 2012), the volumes of windblown sand which accumulated along the coast increased (Roskin et al., 2015 and ref. therein). The initiation and timing of the current wind-induced beach sand build-up is dated to $5 \mathrm{ka}$ in the shallow shelf by Porat et al. (2003), Reinhardt et al. (2006), Goodman-Tchernov et al. (2009), and on the coast mainly by Roskin et al. (2015),
A1.5 m-thick bioclastic sand facies (Figs. 3 and 4), found in the current study in the lowland area of the Alexander stream, was dated to between about 6.6 and $3.3 \mathrm{ka}$ (Table 2). Based on its location, elevation range $(+1.3$ to $+0.3 \mathrm{mILSD})$, the relatively high percentage of the bioclasts, and the covering aeolian sand unit, we suggest that in the stream outlets the sea penetrated inland and created estuaries (Appendix 2). In these areas the coastline reached about $1 \mathrm{~km}$ inland at about $4 \mathrm{ka}$ (Raban and Galili, 1985), and progradated to its current position at about $3 \mathrm{ka}$. These late Holocene embayments resemble, on a smaller scale, those described in Haifa Bay and the Zevulun Plain (Fig.1; Zviely et al., 2006; Porat et al., 2008; Elyashiv et al., 2016). From 6 to $4 \mathrm{ka}$, a sequence of bioclastic sand 1 to $3 \mathrm{~m}$ thick was deposited along most of Israel's coastal cliff. This bioclastic sand eventually calcified to aeolianite (Tel Aviv kurkar) (Fig. 7f; Gvirtzman et al., 1998; Frechen et al., 2002; Porat et al., 2004), although its formation has yet to be properly examined. As the sea level and coastline position stabilized, greater volumes of sand were windblown inland (Fig. $7 \mathrm{f}$ ). The aeolian sand overlaid the lowland areas around the estuaries, and created ridges reaching a thickness of up to $7 \mathrm{~m}$ (Fig. 3; Roskin et al., 2015).

\section{Conclusions}

For the first time the Late Pleistocene history of the coast lowlands of Israel has been examined through a combination of high-resolution petro-sedimentological methods and OSL ages, enabling reconstruction of the palaeogeography and landscape evolution processes. The coastal reconstruction, combined with earlier interpretations of the coastal cliff sequences, reveal that over the last glacial-interglacial cycle the stratigraphy of the coastal plain of Israel was dominated mainly by aeolian, and to a lesser extent, fluvial, processes. The variation in lithology and facies captures six sedimentation cycles and three post-deposition processes (weathering, lithification and pedogenesis).

\section{The conclusions from this study are:}

1. The chronological association between the lowland and coastal cliff sequences reveals dissimilarities in lithologies over time. We propose that these differences, which often occur over distances smaller than $1 \mathrm{~km}$, are the result of local factors, such as the ancient topography and locations of stream courses, which subsequently affected the depositional/erosional rate and soil-forming processes. As a result, two aeolianite units that exist in the coastal cliff are missing in the lowland sequence, and are replaced by thicker and more developed palaeosol units.

2. The fluvial system location did not change considerably from about 80 to $5 \mathrm{ka}$. However, the streams had a profound influence on the stratigraphical composition and related facies, due to fluvial induced erosion which shaped the evolving topography. Consequently, the relief variations between the lowland and cliff controlled aeolian, pedogenesis, and alluvial processes.

3. Correlation between sea-level fluctuations over the last interglacial and the coastal sedimentological sequence shows no distinct influence of sea level on the deposition and formation of the coastal sequence - apart from two periods: during the LGM lowstand (33 to 15 ), and from 15 to $12 \mathrm{ka}$. We suggest that a gap in deposition of about $20 \mathrm{ka}$ was caused by the low RSL from 33 to $15 \mathrm{ka}$, which prevented sediments from reaching the palaeo-coastal plain, while from 15 to $12 \mathrm{ka}$ the rapid transgression outpaced sedimentation supply to the coast.

4. The Holocene sand unit started to accumulate at about $8 \mathrm{ka}$ on the shallow shelf and coastal plain, reaching a thickness of up to $10 \mathrm{~m}$. We propose that the fast coastal build-up was a result of the ero- 
sion of the Nile Delta by the rising sea, and the transgressing shorelines which transported higher fluxes of sand closer to the present shoreline.

The Late Pleistocene landscape evolution described here presents a relevant example for other similar coastal areas across the southern parts of the Mediterranean basin that consist of lowland-ridge morphologies with relatively flat to moderately steep shelf and coast, comprising aeolianites, palaeosol units and alluvial facies, supplied with siliciclastic sediments and desert dust from the Sahara. Such areas include the northern coasts of Egypt, Libya and Tunisia (El-Asmar and Wood, 2000; Mauz et al., 2009, 2012; Elmejdoub et al., 2011). The model could also fit, to some degree, other areas with similar silicate-based lithologies and stratigraphic architecture influenced by Saharan dust deposits. Atlantic westerlies and monsoon circulation are responsible for advecting precipitation in the Mediterranean area in winter. These include the Atlantic shores of south-western Spain (i.e., Huelva and the Gulf of Cadiz; Zazo et al., 2005, 2008) and the Canary Islands (i.e., Lanzarote; von Suchodoletz et al., 2010).

\section{Acknowledgments}

The authors gratefully acknowledge support from the University of Haifa, the Helmsley Charitable Trust Mediterranean Sea Research Center, and the Maurice and Lady Hatter Fund of the Leon Recanati Institute for Maritime Studies (RIMS) at the University of Haifa. We thank Dina Dagan Begun of Ben Gurion University of the Negev and Silas Dean, Benny Bechor and Dr. Guy Sisma-Ventura of the University of Haifa for their vital help in the field. We thank Dr. Avnaim-Katav of the University of Haifa and Dr. Langgut of Tel Aviv University for the palaeontological and pollen analyses. Inga Boianju for preparing the samples for OSL dating, and Dina Stiber and Olga Berlin for chemical analyses, and Jonathan J. Gottlieb of the University of Haifa for preparing the thin sections. Improvements of earlier versions of the manuscript by anonymous reviewers and by Editor-in-Chief (Dr Paul Hesse) are truly appreciated.

\section{Appendix 1}

Thin-section representation of calcareous sandstone samples SY5 $(\mathrm{a}, \mathrm{b})$ and SDC4 (c, d). Skeletal features are SY5 (dashed red polygons), micritic cement (yellow arrows) and quartz grain areas (red arrows).
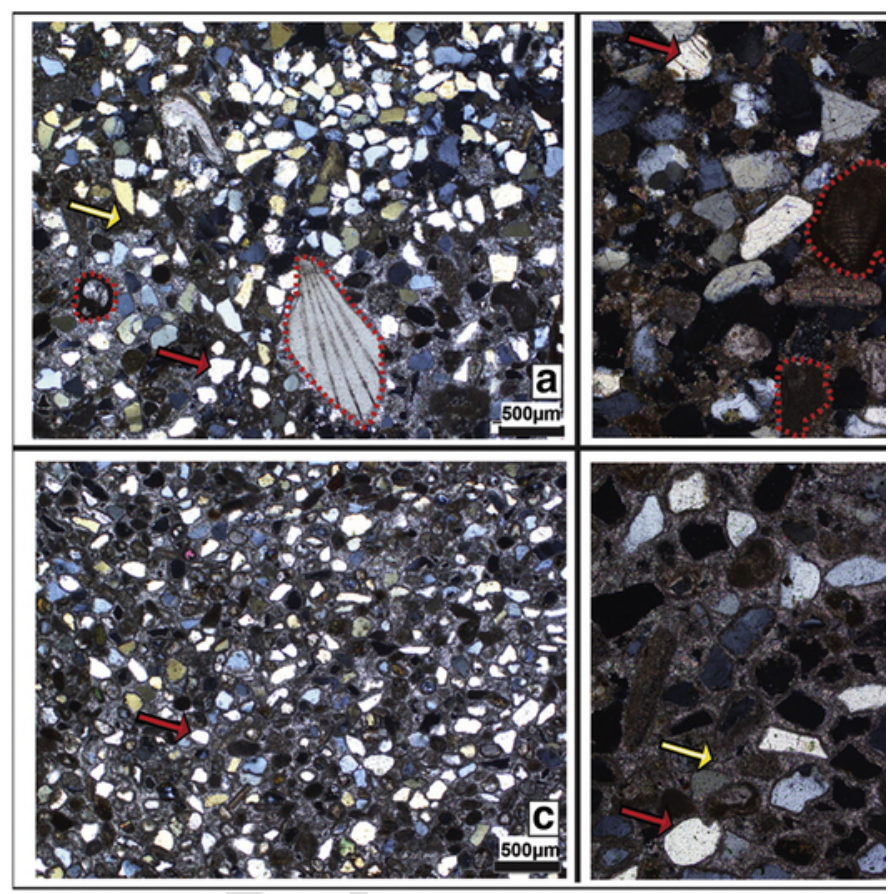

\section{Appendix 2}

Average particle size distribution in Borehole ALX5, presenting the top aeolian sand, bioclastic sand and wetland units. Each curve was created from six samples which represent the three environments.

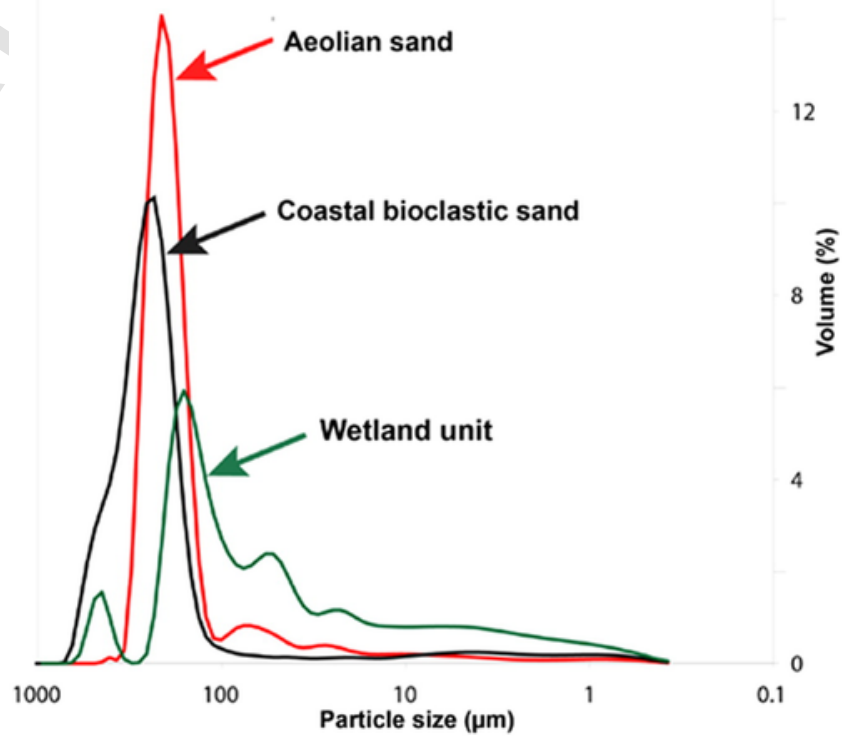




\section{Appendix 3}

The modern topography of Hadera-Alexander (extracted from a $4 \times 4 \mathrm{~m} \mathrm{DEM}$ ) versus the basal calcareous sandstone topography, corresponding borehole and current study OSL ages along (a) NW-SE transect in Hadera (b) W-E transect in Hadera (c) $\mathrm{N}-\mathrm{S}$ transact in Hadera (d) W-E transect in Alexander. The Hadera and Alexander transect and borehole locations are shown in maps (e) and (f) respectively.
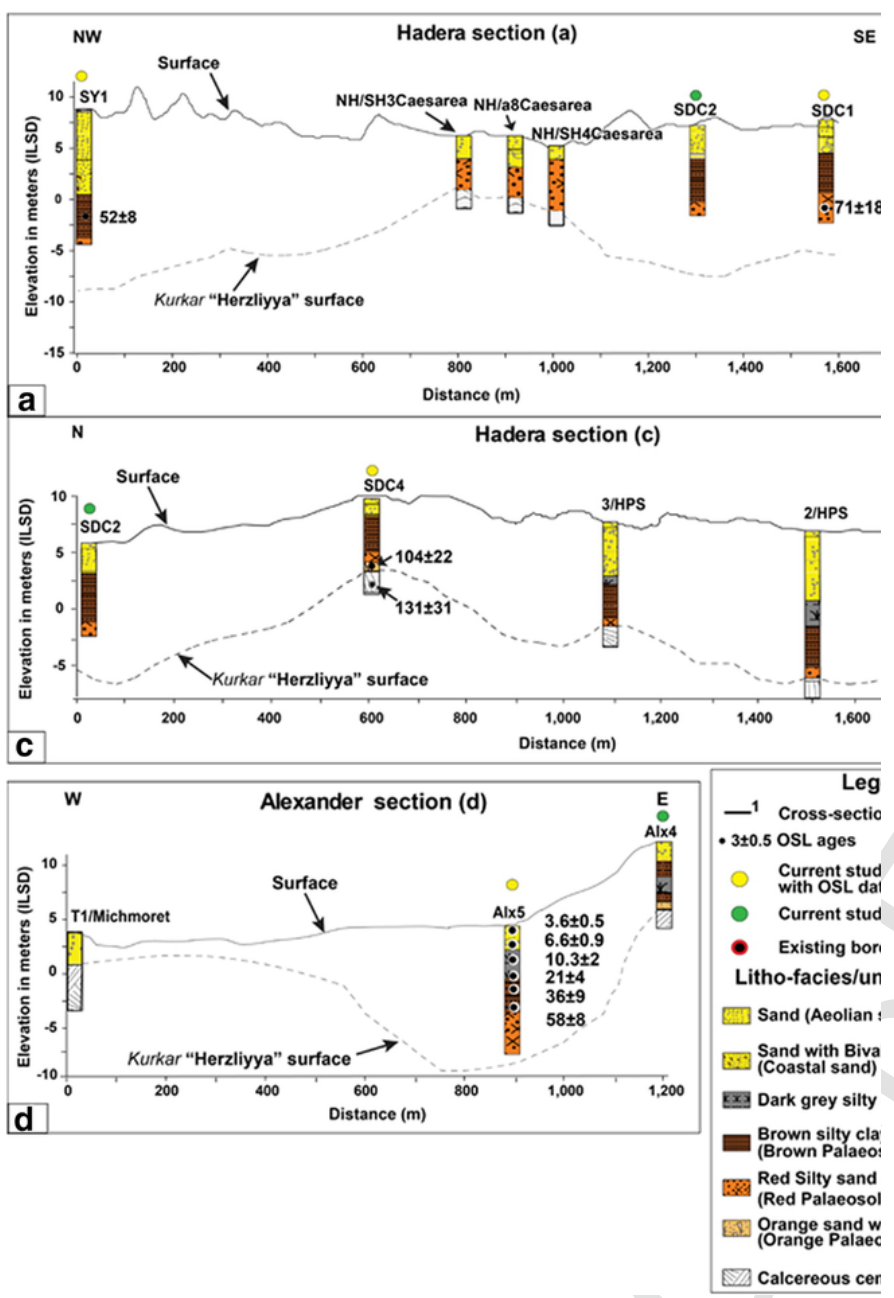

\section{Appendix A. Supplementary data}

Supplementary data to this article can be found online at http://dx. doi.org/10.1016/j.palaeo.2016.12.045.

\section{References}

Adams, A.E., MacKenzie, W.S., 1998. A Color Atlas of Carbonate Sediments and Rocks Under the Microscope. Manson Publishing Ltd., London, UK.
Almagor, G., Hall, J.K., 1984. Morphology of the Mediterranean Contintental Margin of Israel: A Comparative Summary and a Bathymetric Chart. Geological Survey of Israel.

Almogi-Labin, A., Bar-Matthews, M., Shriki, D., Kolosovsky, E., Paterne, M., Schilman, B., Ayalon, A., Aizenshtat, Z., Matthews, A., 2009. Climatic variability during the last $\sim 90 \mathrm{ka}$ of the southern and northern Levantine Basin as evident from marine records and speleothems. Quaternary Science Reviews 28,

2882-2896. Almagor, G., Gill, D., Perath, I., 2000. Marine sand resources offshore Israel. Mar. Georesour. Geotechnol. 18, 1-42.

Amante, C., Eakins, B.W., 2009. ETOPO1 1 Arc-Minute Global Relief Model: Procedures, Data Sources and Analysis. US Department of Commerce, National Oceanic and Atmospheric Administration. National Environmental Satellite, Data, and Information Service, National Geophysical Data Center, Marine Geology and Geophysics Division Colorado.

Amorosi, A., Ricci Lucchi, M., Rossi, V., Sarti, G., 2009. Climate change signature of small-scale parasequences from Lateglacial-Holocene transgressive deposits of the Arno valley fill. Palaeogeogr. Palaeoclimatol. Palaeoecol. 273, 142-152.

Anderson, J.B., Abdulah, K., Sarzalejo, S., Siringan, F., Thomas, M., 1996. Late Quaternary sedimentation and high-resolution sequence stratigraphy of the east Texas shelf. Geol. Soc. Lond., Spec. Publ. 117, 95-124.

Anzidei, M., Antonioli, F., Benini, A., Lambeck, K., Sivan, D., Serpelloni, E., Stocchi, P., 2011. Sea level change and vertical land movements since the last two millennia along the coasts of southwestern Turkey and Israel. Quat. Int. 232, 13-20.

Avnaim-Katav, S., Almogi-Labin, A., Sandler, A., Sivan, D., Porat, N., Matmon, A. 2012. The chronostratigraphy of a quaternary sequence at the distal part of the nile littoral cell, Haifa Bay, Israel. J. Quat. Sci. 27, 675-686.

Avnimelech, M., 1950. The geological history of the Yarkon Valley and its influence on ancient settlements. Israel Explor. J. 1, 77-83.

Bar-Matthews, M., Ayalon, A., Gilmour, M., Matthews, A., Hawkesworth, C.J., 2003. Sea-land oxygen isotopic relationships from planktonic foraminifera and speleothems in the Eastern Mediterranean region and their implication for paleorainfall during interglacial intervals. Geochim. Cosmochim. Acta 67, 3181-3199.

Bateman, M.D., Holmes, P.J., Carr, A.S., Horton, B.P., Jaiswal, M.K., 2004. Aeolianite and barrier dune construction spanning the last two glacial-interglacial cycles from the southern Cape coast, South Africa. Quat. Sci. Rev. 23, 1681-1698.

Ben-David, R., 2003. Changes in Desert Margin Environments during the Climate Changes of the Upper Quaternary. Unpublished Ph. D. Thesis, Hebrew University of Jerusalem.

Blum, M.D., Tōrnqvist, T.E., 2000. Fluvial responses to climate and sea-level change: a review and look forward. Sedimentology 47, 2-48.

Bozzano, G., Kuhlmann, H., Alonso, B., 2002. Storminess control over African dust imput to the Moroccan Atlantic margin (NW Africa) at the time of maxima boreal summer insolation- a record of the last 220 kyr. Palaeogeogr. Palaeoclimatol. Palaeoecol. 183, 155-168.

Brooke, B.P., Woodroffe, C.D., Murray-Wallace, C.V., Heijnis, H., Jones, B.G., 2003. Quaternary calcarenite stratigraphy on Lord Howe Island, southwestern Pacific Ocean and the record of coastal carbonate deposition. Quat. Sci. Rev. 22, 859-880.

Brooke, B.P., Olley, J.M., Pietsch, T., Playford, P.E., Haines, P.W., Murray-Wallace, C.V., Woodroffe, C.D., 2014. Chronology of Quaternary coastal aeolianite deposition and the drowned shorelines of southwestern Western Australia - a reappraisal. Quat. Sci. Rev. 93, 106-124.

Campbell, J.B., 1996. Introduction to Remote Sensing. Virginia Polytechnic Institute and State University. Taylor \& Francis Ltd, London, England.

Cheddadi, R., Rossignol-Strick, M., 1995. Improved preservation of organic matter and pollen in eastern Mediterranean sapropels. Paleoceanography 10, 301-309.

Cita, M.B., Vergnaud-Grazzini, C., Robert, C., Chamley, H., Ciaranfi, N., d'Onofrio, S., 1977. Paleoclimatic record of a long deep sea core from the eastern Mediterranean. Quat. Res. 8, 205-235.

Cohen-Seffer, R., Greenbaum, N., Sivan, D., Jull, T., Barmeir, E., Croitoru, S., Inbar, M., 2005. Late Pleistocene-Holocene marsh episodes along the Carmel coast, Israel. Quat. Int. 140-141, 103-120.

Coltorti, M., Melis, E., Patta, D., 2010. Geomorphology, stratigraphy and facies analysis of some Late Pleistocene and Holocene key deposits along the coast of Sardinia (Italy). Quat. Int. 222, 19-35.

Crouvi, O., Schepanski, K., Amit, R., Gillespie, A.R., Enzel, Y., 2012. Multiple dust sources in the Sahara Desert: the importance of sand dunes. Geophys. Res. Lett. 39, (n/a-n/a)

Dan, J., Yaalon, D.H., Koyumdjisky, H., 1968. Catenary soil relationships in Israel, 1. The Netanya catena on coastal dunes of the Sharon. Geoderma 2, 95-120.

Davidovich, U., Porat, N., Gadot, Y., Avni, Y., Lipschits, O., 2012. Archaeological investigations and OSL dating of terraces at Ramat Rahel, Israel. J. Field Archaeol. 37, 192-208.

Davis, M., Matmon, A., Rood, D.H., Avnaim-Katav, S., 2012. Constant cosmogenic nuclide concentrations in sand supplied from the Nile River over the past $2.5 \mathrm{my}$. Geology 40, 359-362.

Dutton, A., Carlson, A.E., Long, A.J., Milne, G.A., Clark, P.U., DeConto, R., Horton, B.P., Rahmstorf, S., Raymo, M.E., 2015. Sea-level rise due to polar ice-sheet mass loss during past warm periods. Science 349 , aaa4019.

El-Asmar, H.M., 1994. Aeolianite sedimentation along the northwestern coast of Egypt: evidence for middle to late quaternary aridity. Quat. Sci. Rev. 13, 699-708. 
El-Asmar, H.M., Wood, P., 2000. Quaternary shoreline development- the northwestern coast of Egypt. Quat. Sci. Rev. 19, 1137-1149.

Elmejdoub, N., Mauz, B., Jedoui, Y., 2011. Sea-level and climatic controls on late Pleistocene coastal aeolianites in the Cap Bon peninsula, northeastern Tunisia. Boreas 40, 198-207.

Elyashiv, H., 2013. The Late Pleistocene-Holocene Sedimentary Evolution of Zevulun Plain : Focusing on the Wetlands MA Thesis Faculty of Natural Sciences, Leon H. Charney School of Marine Sciences. University of Haifa, Israel, The Dr. Moses Sreauss Dept. of Marine Geosciences.

Elyashiv, H., Bookman, R., Zviely, D., Avnaim-Katav, S., Sandler, A., Sivan, D., 2016. The interplay between relative sea-level rise and sediment supply at the distal part of the Nile littoral cell. The Holocene 26, 248-264.

Emery, K., Neev, D., 1960. Mediterranean beaches of Israel. In: Israel Geological Survey Bulletin. 26, pp. 1-24.

Engelmann, A., Neber, A., Frechen, M., Boenigk, W., Ronen, A., 2001. Luminescence chronology of Upper Pleistocene and Holocene aeolianites from Netanya South Sharon Coastal Plain, Israel. Quat. Sci. Rev. 20, 799-804.

Enzel, Y., Amit, R., Dayan, U., Crouvi, O., Kahana, R., Ziv, B., Sharon, D., 2008. The climatic and physiographic controls of the eastern Mediterranean over the late Pleistocene climates in the southern Levant and its neighboring deserts. Glob. Planet. Chang. 60, 165-192.

Faust, D., Yanes, Y., Willkommen, T., Roettig, C., Richter, D., Richter, D., Suchodoletz, H.v., Zöller, L., 2015. A contribution to the understanding of late Pleistocene dune sand-paleosol-sequences in Fuerteventura (Canary Islands). Geomorphology 246, 290-304.

Fitzsimmons, K.E., Magee, J.W., Amos, K.J., 2009. Characterisation of aeolian sediments from the Strzelecki and Tirari Deserts, Australia: implications for reconstructing palaeoenvironmental conditions. Sediment. Geol. 218, 61-73.

Fornós, J.J., Clemmensen, L.B., Gómez-Pujol, L., Murray, A.S., 2009. Late Pleistocene carbonate aeolianites on Mallorca, Western Mediterranean: a luminescence chronology. Quat. Sci. Rev. 28, 2697-2709.

Frechen, M., Dermann, B., Beonigk, W., Ronen, A., 2001. Luminesence chronology of the aeolianites from the section at givat olga-coastal plain of Israel. Quat. Sci. Rev. 20, 805-809.

Frechen, M., Neber, A., Dermann, B., Alexander, T., Boenigk, W., Raban, A., 2002 Chronostratigraphy of aeolianites from the Sharon Coastal Plain of Israel. Quat. Int. 31-44.

Frechen, M., Neber, A., Tsatskin, A., Boenigk, W., Ronen, A., 2004. Chronology of Pleistocene sedimentary cycles in the Carmel Coastal Plain of Israel. Quat. Int. $121,41-52$.

Galili, E., Zviely, D., Ronen, A., Mienis, H.K., 2007. Beach deposits of MIS 5e high sea stand as indicators for tectonic stability of the Carmel coastal plain, Israel. Quat. Sci. Rev. 26, 2544-2557.

Gavish, E., Friedman, G.M., 1969. Progressive diagenesis in Quaternary to Late Tertiary carbonate sediments: sequence and time scale. J. Sediment. Res. 39, 980-1006.

Goodman-Tchernov, B.N., Dey, H.W., Reinhardt, E.G., McCoy, F., Mart, Y., 2009. Tsunami waves generated by the Santorini eruption reached Eastern Mediterranean shores. Geology 37, 943-946.

Gvirtzman, G., Shachnai, E., Bakler, N., Ilani, S., 1983. Stratigraphy of the Kurkar Group (Quaternary) of the coastal plain of Israel. In: Geological Survey of Israel, Current Research 1984. pp. 70-82.

Gvirtzman, G., Netser, M., Katsav, E., 1998. Last-Glacial to Holocene kurkar ridges, hamra soils, and dune fields in the coastal belt of central Israel. Isr. J. Earth Sci. 47, 27-46.

Gvirtzman, G., Wieder, M., 2001. Climate of the last 53,000 years in the eastern med based on soil-sequence stratigraphy in coastal plain Israel. Quat. Sci. Rev. 20, 1827-1849.

Hall, J.K., 1994. Bathymetric chart of the eastern Mediterranean Sea. Geologic Structure of the Northen Mediterranean (Cruise 5 of the Akademic Nikolaj Strakhov).

Hearty, P.J., Hollin, J.T., Neumann, A.C., O'Leary, M.J., McCulloch, M., 2007. Global Sea-level fluctuations during the Last Interglaciation (MIS 5e). Quat. Sci. Rev. 26, 2090-2112.

Huntley, D., Hutton, J., Prescott, J., 1993. The stranded beach-dune sequence of south-east South Australia: a test of thermoluminescence dating, 0-800 ka. Quat. Sci. Rev. 12, 1-20.

Huntley, D., Hutton, J., Prescott, J., 1994. Further thermoluminescence dates from the dune sequence in the southeast of South Australia. Quat. Sci. Rev. 13, 201-207.

Huntley, D.J., Prescott, J.R., 2001. Improved methodology and new thermoluminescence ages for the dune sequence in the south-east south Australia. Quat. Sci. Rev. 20, 687-699.

Hyams-Kaphzan, O., Almogi-Labin, A., Sivan, D., Benjamini, C., 2008. Benthic foraminifera assemblage change along the southeastern Mediterranean inner shelf due to fall-off of Nile-derived siliciclastics. Neues Jb. Geol. Paläontol. Abh. 248, 315-344.

Imbrie, J., Hays, J.D., Martinson, D.G., McIntyre, A., Mix, A.C., Morley, J.J., Pisias, N.G., Prell, W.L., Shackleton, N.J., 1984. The orbital theory of Pleistocene climate: Support from a revised chronology of the marine delta $18 \mathrm{O}$ record, $\mathrm{Mi}$ lankovitch and climate: Understanding the response to astronomical forcing, $\mathrm{p}$. 269.
A late quaternary paleoenvironmental sequence from Dor, Carmel coastal plain, Israel. Palynology 28, 143-157.

Katz, O., Mushkin, A., 2013. Characteristics of sea-cliff erosion induced by a strong winter storm in the eastern Mediterranean. Quat. Res. 80, 20-32.

Kopp, R.E., Simons, F.J., Mitrovica, J.X., Maloof, A.C., Oppenheimer, M., 2009. Probabilistic assessment of sea level during the last interglacial stage. Nature 462, 863-867.

Kopp, R.E., Simons, F.J., Mitrovica, J.X., Maloof, A.C., Oppenheimer, M., 2013. A probabilistic assessment of sea level variations within the last interglacial stage. Geophys. J. Int. 193, 711-716.

Lambeck, K., Bard, E., 2000. Sea-level change along the French Mediterranean coast for the past 30,000 years. Earth Planet. Sci. Lett. 175, 203-222.

Lambeck, K., Purcell, A., 2005. Sea-level change in the Mediterranean Sea since the LGM: model predictions for tectonically stable areas. Quat. Sci. Rev. 24, 1969-1988.

Langgut, D., Almogi-Labin, A., Bar-Matthews, M., Weinstein-Evron, M., 2011. Vegetation and climate changes in the South Eastern Mediterranean during the Last Glacial-Interglacial cycle (86 ka): new marine pollen record. Quat. Sci. Rev. 30, 3960-3972.

Larrasoaña, J.C., Roberts, A.P., Rohling, E.J., 2008. Magnetic susceptibility of eastern Mediterranean marine sediments as a proxy for Saharan dust supply?. Mar. Geol. 254, 224-229.

Lourens, L., Antonarakou, A., Hilgen, F., Van Hoof, A., Vergnaud-Grazzini, C., Zachariasse, W., 1996. Evaluation of the Plio-Pleistocene astronomical timescale. Paleoceanography 11, 391 (Olsen, PE, DV Kent, B. Cornet, WK Witte, and RW Schlische, High-resolution stratigraphy of the Newark rift basin (early Mesozoic, eastern North America). Geol. Soc. Am. Bull 108, 40).

Mauz, B., Elmejdoub, N., Nathan, R., Jedoui, Y., 2009. Last interglacial coastal environments in the Mediterranean-Saharan transition zone. Palaeogeogr. Palaeoclimatol. Palaeoecol. 279, 137-146.

Mauz, B., Fanelli, F., Elmejdoub, N., Barbieri, R., 2012. Coastal response to climate change: Mediterranean shorelines during the Last Interglacial (MIS 5). Quat. Sci. Rev. 54, 89-98.

Mauz, B., Hijma, M.P., Amorosi, A., Porat, N., Galili, E., Bloemendal, J., 2013. Aeolian beach ridges and their significance for climate and sea level: concept and insight from the Levant coast (East Mediterranean). Earth Sci. Rev. 121, 31-54.

McGee, D., Broecker, W.S., Winckler, G., 2010. Gustiness: the driver of glacial dustiness?. Quat. Sci. Rev. 29, 2340-2350.

Mor-Federman, T., 2012. Chemical Characterization and Provenance Study of the Israeli Inner Shelf's Holocene Sediments. MS.c Thesis Marine Geo-Sciences. The University of Haifa, Haifa (in Hebrew, English abstract).

Moshier, S., Master, D., Leport, J., Wheatley, D., Felker, B., Lavigne, E., College, W., 2010. Reconstruction of the Ancient Landscapes and Paleoenvitonments of the Geological Foundations of the Ancient Seaport Ashkelon, Israel. GSA Annual Meeting \& Exposition, Minneapolis, Minnesota USA.

Munyikwa, K., 2005. Synchrony of Southern Hemisphere Late Pleistocene arid episodes: a review of luminescence chronologies from arid aeolian landscapes south of the Equator. Quat. Sci. Rev. 24, 2555-2583.

Murray, A.S., Wintle, A.G., 2000. Luminescence dating of quartz using an improved single-aliquot regenative-dose protocol. Radiat. Meas. 32, 57-73.

Neber, A., 2002. Sedimentological Properies of Quternary Deposits on the Central Coastline of Israel. Unpublished Ph.D. Dissertation. Department of Archaeology, University of Haifa, Israel.

Neev, D., Schanai, E., Hall, J.K., Bakler, N., Ben-Avraham, Z., 1978. The young (Post Lower Pliocene) geological history of the Caesarea. Isr. J. Earth Sci. 28, 43-46.

Paton, T.R., Humphreys, G.S., Mitchell, P.B., 1995. Soils: A New Global View. Yale University Press, New Haven and London.

Picard, L., 1943. Structure and evolution of Palestine. In: Bull. Geol. Dept. Hebrew Univ., Jerusalem. 4, pp. 1-134.

Pomerancblum, M., 1966. The distribution of heavy minerals and their hydraulic equivalents in sediments of the Mediterranean continental shelf of Israel. J. Sediment. Res. 36.

Porat, N., Avital, A., Frechen, M., Almogi-Labin, A., 2003. Chronology of upper quaternary offshore successions from the southeastern Mediterranean Sea, Israel. Quat. Sci. Rev. 22, 1191-1199.

Porat, N., Wintle, A.G., Ritte, M., 2004. Mode and timing of kurkar and hamra formation, central coastal plain, Israel. Isr. J. Earth Sci. 53, 13-25.

Porat, N., Sivan, D., Zviely, D., 2008. Late Holocene embayment infill and shoreline migration, Haifa Bay, Eastern Mediterranean. Isr. J. Earth Sci. 57, 21-31.

Porath, Y., 1975. The Gardens of Caesarea. Qadmoniot 30-31.

Posamentier, H.W., Allen, G.P., James, D.P., Tesson, M., 1992. Forced regressions in a sequence stratigraphic framework: concepts, examples, and exploration significance (1). AAPG Bull. 76, 1687-1709.

Preusser, F., Radies, D., Matter, A., 2002. A 160,000-year record of dune develop and atmospheric circulation in the Southern Arabia. Science 296, 2018-2020.

Raban, A., Galili, E., 1985. Recent maritime archaeological research in Israel-A preliminary. Int. J. Naut. Archaeol. Underw. Explor. 14, 321-356.

Reinhardt, E.G., Goodman, B.N., Boyce, J.I., Lopez, G., van Hengstum, P., Rink, W.J., Mart, Y., Raban, A., 2006. The tsunami of 13 December A.D. 115 and the 
destruction of Herod the Great's harbor at Caesarea Maritima, Israel. Geology 34,1061 .

Revel, M., Ducassou, E., Grousset, F.E., Bernasconi, S.M., Migeon, S., Revillon, S., Mascle, J., Murat, A., Zaragosi, S., Bosch, D., 2010. 100,000 Years of African monsoon variability recorded in sediments of the Nile margin. Quat. Sci. Rev. 29, 1342-1362.

Rohling, E.J., Foster, G.L., Grant, K.M., Marino, G., Roberts, A.P., Tamisiea, M.E., Williams, F., 2014. Sea-level and deep-sea-temperature variability over the past 5.3 million years. Nature 508, 477-482.

Rose, J., Meng, X., Watson, C., 1999. Palaeoclimate and palaeoenvironmental responses in the western Mediterranean over the last $140 \mathrm{ka}$ : evidence from Mallorca, Spain. J. Geol. Soc. 156, 435-448.

Roskin, J., Katra, I., Porat, N., Zilberman, E., 2013. Evolution of Middle to Late Pleistocene sandy calcareous paleosols underlying the northwestern Negev Desert Dunefield (Israel). Palaeogeography, Palaeoclimatology, Palaeoecology 387, 134-152. Roskin, J., Porat, N., Tsoar, H., Blumberg, D.G., Zander, A.M., 2011. Age, origin and climatic controls on vegetated linear dunes in the northwestern Negev Desert (Israel). Quat. Sci. Rev. 30, 1649-1674.

Roskin, J., Tsoar, H., Porat, N., Blumberg, D.G., 2011. Palaeoclimate interpretations of Late Pleistocene vegetated linear dune mobilization episodes: evidence from the northwestern Negev dunefield, Israel. Quat. Sci. Rev. 30, 3364-3380.

Roskin, J., Sivan, D., Shtienberg, G., Roskin, E., Porat, N., Bookman, R., 2015. Natural and human controls of the Holocene evolution of the beach, aeolian sand and dunes of Caesarea (Israel). Aeolian Res. 19, 65-85.

Roskin, J., Sivan, D., Bookman, R., Porat, N., Shtienberg, G., 2016. Beach Buildup and Coastal Aeolian Sand Incursions off the Nile Cell During the Holocene Poster Presented in the Annual IGRG Congress; the University of Haifa. 33.

Rowe, M.P., Bristow, C.S., 2015. Landward-advancing Quaternary eolianites of Bermuda. Aeolian Res. 19, 235-249.

Rowe, M.P., Bristow, C.S., 2015. Sea-level controls on carbonate beaches and coastal dunes (eolianite): lessons from Pleistocene Bermuda. Geol. Soc. Am. Bull. 127, $1645-1665$.

Sade, A.R., Hall, J.K., Amit, G., Golan, A., Gur-Arieh, L., Tibor, G., 2006. The Israel national bathymetric survey - a new look at the seafloor off Israel. Isr. J. Earth Sci. 55, 185-187.

Schattner, U., Lazar, M., Tibor, G., Ben-Avraham, Z., Makovsky, Y., 2010. Filling up the shelf - a sedimentary response to the last post-glacial sea rise. Mar. Geol. 278, 165-176.

Schattner, U., Gurevich, M., Kanari, M., Lazar, M., 2015. Levant jet system - effect of post LGM seafloor currents on Nile sediment transport in the eastern Mediterranean. Sediment. Geol. 329, 28-39.

Shtienberg, G., Dix, J., Waldmann, N., Makovsky, Y., Golan, A., Sivan, D., 2016. Late-Pleistocene evolution of the continental shelf of central Israel, a case study from Hadera. Geomorphology 261, 200-211.

Sivan, D., Gvirtzman, G., Sass, E., 1999. Quaternary stratigraphy and paleogeography of the Galilee Coastal Plain, Israel. Quat. Res. 51, 280-294.

Sivan, D., Widowinski, S., Lambeck, K., Galili, E., Raban, A., 2001. Holocene sea level changes based on archeological sites off northern Israel. Palaeogeogr. Palaeoclimatol. Palaeoecol. 167, 101-117.

Sivan, D., Lambeck, K., Toueg, R., Raban, A., Porath, Y., Shirman, B., 2004. Ancient coastal wells of Caesarea Maritima, Israel, an indicator for relative sea level changes during the last 2000 years. Earth Planet. Sci. Lett. 222, 315-330.

Sivan, D., Porat, N., 2004. Evidence from luminescence for Late Pleistocene formation of calcareous aeolianite (kurkar) and paleosol (hamra) in the Carmel Coast, Israel. Palaeogeogr. Palaeoclimatol. Palaeoecol. 211, 95-106.

Sivan, D., Greenbaum, N., Cohen-Seffer, R., Sisma-Ventura, G., Almogi-Labin, A., 2011. The origin and disappearance of the late Pleistocene-early Holocene short-lived coastal wetlands along the Carmel coast, Israel. Quat. Res. 76, 83-92.

Sivan, D., Sisma-Ventura, G., Greenbaum, N., Bialik, O.M., Williams, F.H., Tamisiea, M.E., Rohling, E.J., Frumkin, A., Avnaim-Katav, S., Shtienberg, G., Stein, M., 2016. Eastern Mediterranean sea levels through the last interglacial from a coastal-marine sequence in northern Israel. Quat. Sci. Rev. 145, 204-225.

Spratt, R.M., Lisiecki, L.E., 2015. A Late Pleistocene sea level stack. Clim. Past Discuss. 11, 3699-3728.
Stanley, D.J., Warne, A.G., 1998. Nile Delta in its destruction phase. J. Coast. Res. 14, 794-825.

von Suchodoletz, H., Oberhänsli, H., Hambach, U., Zöller, L., Fuchs, M., Faust, D., 2010. Soil moisture fluctuations recorded in Saharan dust deposits on Lanzarote (Canary Islands) over the last $180 \mathrm{ka}$. Quat. Sci. Rev. 29, 2173-2184.

Suter, J.R., Berryhill Jr, H.L., 1985. Late Quaternary shelf-margin deltas, northwest Gulf of Mexico. AAPG Bull. 69, 77-91.

Thiel, C., Coltorti, M., Tsukamoto, S., Frechen, M., 2010. Geochronology for some key sites along the coast of Sardinia (Italy). Quat. Int. 222, 36-47.

Thomsen, K.J., Murray, A.S., Jain, M., Bøtter-Jensen, L., 2008. Laboratory fading rates of various luminescence signals from feldspar-rich sediment extracts. Radiation Measurements 43, 1474-1486. Toker, E., Sivan, D., Stern, E., Shirman, B., Tsimplis, M., Spada, G., 2012. Evidence for centennial scale sea level variability during the Medieval Climate Optimum (Crusader Period) in Israel, eastern Mediterranean. Earth Planet. Sci. Lett. 315-316, 51-61.

Tripaldi, A., Forman, S.L., 2007. Geomorphology and chronology of Late Quaternary dune fields of western Argentina. Palaeogeogr. Palaeoclimatol. Palaeoecol. 251, 300-320.

Tsakalos, E., 2015. Geochronology and exoscopy of quartz grains in environmental determination of coastal sand dunes in SE Cyprus. J. Archaeol. Sci. Rep.

Tsatskin, A., Ronen, A., 1999. Micromorphology of a Mousterian paleosol in aeolianites at the site Habonim, Israel. Catena 34, 365-384.

Tsatskin, A., Gendler, T.S., Heller, F., Ronen, A., 2008. Near-surface paleosols in coastal sands at the outlet of Hadera stream (Israel) in the light of archeology and luminescence chronology. J. Plant Nutr. Soil Sci. 171, 524-532.

Tsatskin, A., Gendler, T.S., Heller, F., Dekman, I., Frey, G.L., 2009. Towards understanding paleosols in Southern Levantine eolianites: integration of micromorphol ogy, environmental magnetism and mineralogy. J. Mt. Sci. 6, 113-124.

Tsatskin, A., Sandler, A., Avnaim-Katav, S., 2015. Quaternary subsurface paleosols in Haifa Bay, Israel: a new perspective on stratigraphic correlations in coastal settings. Palaeogeogr. Palaeoclimatol. Palaeoecol. 426, 285-296.

Waelbroeck, C., Labeyrie, L., Michel, E., Duplessy, J.C., McManus, J., Lambeck, K. Balbon, E., Labracherie, M., 2002. Sea-level and deep water temperature changes derived from benthic foraminifera isotopic records. Quat. Sci. Rev. 21, 295-305.

Wright, C.I., Tucker, M.E., 1991. Calcretes. Blackwell Scientific Publications, Oxford, UK.

Wright, V., 1992. A revised classification of limestones. Sediment. Geol. 76, 177-185.

Yaalon, D.H., 1967. Factors affecting the lithification of eolianite and interpretation of its environmental significance in the coastal plain of Israel. J. Sediment. Res. 37, 1189-1199.

Yaalon, D., Dan, J., 1967. Factors controlling soil formation and distribution in the Mediterranean coastal plain of Israel during the Quaternary. In: Quaternary Soils. pp. 321-338.

Yaalon, D.H., 1997. Soils in the Mediterranean region- what makes them diffrent? Catena 28, 157-169.

Zazo, C., Mercier, N., Silva, P.G., Dabrio, C.J., Goy, J.L., Roquero, E., Soler, V., Borja, F., Lario, J., Polo, D., de Luque, L., 2005. Landscape evolution and geodynamic controls in the Gulf of Cadiz (Huelva coast, SW Spain) during the late quaternary. Geomorphology 68, 269-290.

Zazo, C., Mercier, N., Lario, J., Roquero, E., Goy, J.-L., Silva, P.G., Cabero, A., Borja, F., Dabrio, C.J., Bardají, T., Soler, V., García-Blázquez, A., Luque, L.d., 2008. Palaeoenvironmental evolution of the Barbate-Trafalgar coast (Cadiz) during the last $\sim 140$ ka: climate, sea-level interactions and tectonics. Geomorphology $100,212-222$.

Zilberman, E., Porat, N., Roskin, J., 2007. The middle to Late-Pleistocene sand sheet sequence of Kerem Shalom, western Negev - an archive of coastal sand incursion. Geological Survey of Israel GSI/13/2007, 23p. Zviely, D., Sivan, D., Ecker, A., Bakler, N., Rohrlich, V., Galili, E., Boarreto, E., Klein, M., Kit, E., 2006. Holocene evolution of the Haifa Bay area, Israel, and its influence on ancient tell settlements. The Holocene 849-861.

Zviely, D., Kit, E., Rosen, B., Galili, E., Klein, M., 2009. Shoreline migration and beach-nearshore sand balance over the last 200 years in Haifa Bay (SE Mediterranean). Geo-Mar. Lett. 29, 93-110. 